\title{
Experimental and finite element analysis of hybrid fiber reinforced concrete two-way slabs at ultimate limit state
}

\author{
Qaiser uz Zaman Khan ${ }^{1} \cdot$ Muhammad Ali $^{2} \cdot$ Afaq Ahmad $^{1}$ (D) Ali Raza ${ }^{3} \cdot$ Muhammad Iqbal $^{4}$
}

Received: 3 September 2020 / Accepted: 24 December 2020 / Published online: 11 January 2021

(c) The Author(s) 2021 OPEN

\begin{abstract}
Concrete is a brittle material that is weak in tension and is prone to internal microcracking. With the constant demand for improvement in concrete's durability and mechanical proprieties, the use of fiber reinforcements has shown promising results. The findings of this paper are based on test results on hybrid fiber reinforced concrete (HFRC) samples of simply supported two-way slabs, produced with a selected volumetric proportion of steel fiber (SF) and polypropylene fibers (PPF). A total of twenty-one specimens were fabricated. Concrete slab specimens were tested under flexural loading and their response in terms of strain, deflection, first crack, and ultimate failure loading was determined. The dosage of SF in concrete ranged from 0.7 to $1.0 \%$, whereas $0.1-0.9 \%$ PPF was used by volume of concrete. It was found that a combination of $0.9 \%$ SF and $0.1 \%$ PPF gave favorable results for loading capacity, ductility, and cracks. A Finite Element Analysis (FEA) of the proposed HFRC two-way slabs was also performed via ABAQUS. The outputs from numerical modeling showed a close agreement with the experimental results. Using the selected FEA model, an extensive parametric study was also done to examine the effect of various parameters including longitudinal reinforcement ratio, compressive strength of concrete, and the concrete cover of specimens. The proposed FEA model presented a close agreement with the experimental outcomes.
\end{abstract}

Keywords Two-way slabs · Finite element analysis · Load-carrying capacity · Fiber reinforcement · Crack patterns

\section{List of symbols}

$f_{c}^{\prime} \quad$ Compressive strength of concrete

$\varepsilon_{c} \quad$ Ultimate strain of plain concrete

$f_{c m} \quad$ Compressive strength of reinforced concrete

$f_{t}^{\prime} \quad$ Ultimate tensile stress of concrete

$\varepsilon_{c, 1} \quad$ Strain of concrete at ultimate compressive strength

$\rho_{l} \quad$ Main reinforcement ratio in slabs

$\varepsilon_{c, u} \quad$ Ultimate strain of concrete at failure

$E_{c m} \quad$ Elastic modulus of reinforced concrete

\section{Introduction}

Concrete is a widely used construction material, but it carries some limitations in properties such as tensile strength, post-cracking, ductility, fatigue resistance and has brittle failure [1, 2]. The brittleness of concrete with its increased strength is the main concern of concrete. Therefore, increasing the strength of concrete leads to lower ductility which is a serious drawback of using concrete in construction works. This drawback between strength and ductility of concrete can be compensated by incorporating short fibers [3]. Micro-cracks produced in concrete cause the weakness in the resistive properties of concrete which can

Afaq Ahmad, afaq.ahmad@uettaxila.edu.pk; Qaiser uz Zaman Khan, dr.qaiser@uettaxila.edu.pk; Muhammad Ali, muhammad.ali@ port.ac.uk; Ali Raza, aliraza@piet.edu.pk; Muhammad Iqbal, afaq.ahmad@uettaxila.edu.pk|'Department of Civil Engineering, University of Engineering and Technology, Taxila 47080, Pakistan. ${ }^{2}$ School of Civil Engineering and Surveying, University of Portsmouth, Portsmouth 03801, UK. ${ }^{3}$ Department of Civil Engineering, Pakistan Institute of Engineering and Technology, Multan 66000, Pakistan. ${ }^{4}$ Creative Engineering and Management Solutions, Deans Centre Peshawar, Peshawar 25000, Pakistan. 
be reduced by using different fibers [4]. Steel fibers (SF) are usually used to increase the ductility and crack resistance of concrete. In tunnel linings, slabs, and concrete pavements, it was examined that it is advantageous to use $0.5 \%$ $\mathrm{SF}$ by volume [5-8]. However, for controlling the shrinkage cracks, a low-volume fraction of $0.1 \%$ polypropylene fibers (PPF) and glass fibers (GF) by volume is suggested $[9,10]$.

The enhancement of the compressive strength of concrete occurs due to the addition of hybrid fibers. This enhancement has resulted from a good mechanical bond between the cement matrix and fibers causing the delay in micro-crack formation [11]. The addition of hybrid fibers bridges the cracks more effectively and enhances the flexural strength, splitting tensile strength, and flexural toughness of concrete. Moreover, the hybrid fibers are more effective in arresting the micro and macro cracks $[12,13]$. The incorporation of single fibers has no significant effect on the compressive strength but improves the tensile and flexural performance of concrete $[14,15]$. Steel fibers are efficient to increase the ductility and resistance to cracking in concrete. Moreover, the shrinkage cracks can be controlled by using a volumetric ratio of $0.1 \%$ of steel and glass fibers [16]. However, a combination of various fibers is found to be efficient for the improvement of different mechanical properties, impact, and blast resistance of concrete under normal and elevated temperatures [17-19].

In the literature, the researchers traditionally worked on the experimental performance of fiber-reinforced slabs. Labib [20] explored the structural performance of HFRC (steel and polypropylene fibers) slabs in terms of their punching failure mechanism and concluded that the punching shear behavior if significantly improved by adding the hybrid fibers instead of plain concrete or by using one type of fiber. Meng et al. [21] investigated the behavior of SF reinforced alkali-activated geopolymer concrete slabs that were exposed to the natural gas explosion and portrayed that these types of specimens can significantly withstand the methane gas explosion. After investigating the performance of steel fiber reinforced concrete slabs for the service loads, McMahon and Birely [22] concluded that the steel fibers can be used in a bridge deck to satisfy its service performance. The experimental study on the HFRC slabs depicted that the punching shear behavior of HFRC slabs performed in a good manner due to the addition of hybrid fibers [23]. The addition of hybrid fibers in the slabs and concrete bridge decks significantly improve the resistance against the punching failure and increase the ductility and load-carrying capacity of slabs [24, 25].

It consumes a lot of money and time to cast the largescale specimens of structural members and analyze them. To overwhelm this problem, one can move towards the nonlinear finite element analysis (FEA). By comparing with experiments, finite element work saves time and cost by simulating the models which can predict the structural performance and complexity of damage behavior of members accurately [26]. The numerical model should not be complex concerning mesh sizes and element types and there should be a balance among these parameters to reduce the analysis time and to increase the accuracy of the results. Therefore, finite element simulations with strong background knowledge are more economical and efficient methods and can be used as a convenient tool for engineering research [27]. Extensive research has been performed in the literature for finite element modeling of fiber-reinforced specimens $[28,29]$. However, none of the researchers proposed the numerical model for predicting the structural performance of HFRC two-way slab specimens.

The purpose of this research is to examine the effects of hybrid fibers on the structural performance of two-way slabs. For this in the Sect. 2, there is detail discussion about the materials used for the casting of 21 two-way HFRC slab specimens reinforced with various ratios of SF and PPF., and tested under center-point loading to determine their load-deflection and cracking behavior. In the Sect. 3, a finite element model was proposed using the experimental results of load-deflection curves for predicting the performance of HFRC two-way slabs accurately and to perform an extensive parametric study for investigating the sensitivity of different parameters such as material properties and geometric configurations of two-way slabs. In the Sect. 4, the experimental results of 21 two-way HFRC slab are discussed in detail. In the Sect. 5, the comparative discussion about the experimental and numerical results are discussed. The significance of the present work is to implement the hybrid fibers in the construction industry after studying the different critical parameters such as ultimate capacity, deflection, and cracking behavior, and ductility of slabs due to the incorporation of hybrid fibers. In the last Sect. 6 , by using the calibrated numerical models, 3D parametric investigation is conducted for the load carrying capacity of two-way HFRC slab.

\section{Testing program}

\subsection{Materials}

Ordinary Portland cement (OPC) according to ASTM Type-I, 43 Grade [30] was used to act as a binding material. Some physical properties of OPC are shown in Table 1. The coarse aggregate passing through sieve size of $25 \mathrm{~mm}$ and retained over sieve size of $4.75 \mathrm{~mm}$ arranged from Margalla Crush Plants have been used, whereas the fine aggregate passing through sieve $9.5 \mathrm{~mm}$ and retained over sieve size of $150 \mu \mathrm{m}$ taken from Laurancepur was 
Table 1 Physical properties of cement

\begin{tabular}{lllllll}
\hline Consistency & Initial setting time & Final setting time & Soundness & Fineness & Specific gravity & $\begin{array}{l}\text { Compressive strength of mortar cubes } \\
\text { (28 days) }\end{array}$ \\
\hline $28.75 \%$ & $1 \mathrm{~h}$ and $31 \mathrm{~min}$ & $3 \mathrm{~h} \& 45 \mathrm{~min}$ & No expansion & $3190 \mathrm{~cm}^{2} / \mathrm{g}$ & 3.03 & $41.1 \mathrm{MPa}$ \\
\hline
\end{tabular}

Table 2 Properties of fine-aggregate sand coarse-aggregates used in testing

\begin{tabular}{lllc}
\hline S. No & Description & Fine-aggregates & $\begin{array}{c}\text { Coarse- } \\
\text { aggre- } \\
\text { gates }\end{array}$ \\
\hline 1 & Specific gravity (SG) & 2.67 & 2.71 \\
2 & Fineness modulus & 2.40 & - \\
3 & Water absorption & $1.21 \%$ & $0.82 \%$ \\
\hline
\end{tabular}

Table 3 Physical properties of fibers

\begin{tabular}{llll}
\hline Sr. No & Description & $\begin{array}{l}\text { Hooked } \\
\text { end steel } \\
\text { fiber }\end{array}$ & $\begin{array}{l}\text { Fibrillated } \\
\text { polypropylene } \\
\text { fiber }\end{array}$ \\
\hline 1 & Length $(\mathrm{mm})$ & 38 & 14 \\
2 & Diameter & $0.5 \mathrm{~mm}$ & $22 \mu \mathrm{m}$ \\
3 & Aspect ratio & 76 & - \\
4 & Specific gravity & 7.85 & 0.91 \\
5 & Tensile strength $(\mathrm{MPa})$ & 1100 & 400 \\
6 & Melting point & $2530^{\circ} \mathrm{C}$ & $1700{ }^{\circ} \mathrm{C}$ \\
7 & Young's modulus $\left(\mathrm{kN} / \mathrm{mm}^{2}\right)$ & 20 & 0.45 \\
8 & Elongation at failure & $3.5 \%$ & $15 \%$ \\
9 & Thermal conductivity & Low & - \\
\hline
\end{tabular}

used as fine aggregate in the concrete mix according to [31]. Properties of fine and coarse aggregates based on laboratory testing are described in Table 2.

The fibers used in this research were steel fibers and polypropylene fibers. The physical properties of these fibers are given in Table 3. Dramix $3 D$ is a hooked ended cold drawn wire fiber. ASTM A-820 [32] specifies its classification as Type-I fiber. For even dispersion through the matrix, it is manufactured as glued in bundled. This type of fiber is mainly used in the mining industry. The construction industry is preferring the use of these fibers in tunneling and underground projects. In Pakistan, these fibers were used in the "Neelam Jhelum Project" for tunneling in Dam. Polypropylene fibers employed for this research work are known as Chemrite polypropylene fibers. These fibers help in reducing the plastic and drying cracks while improving the surface properties and durability of concrete. Both types of fibers were presented in Fig. 1.

The workability of the concrete mixture is decreased by the addition of different types of fibers [33].
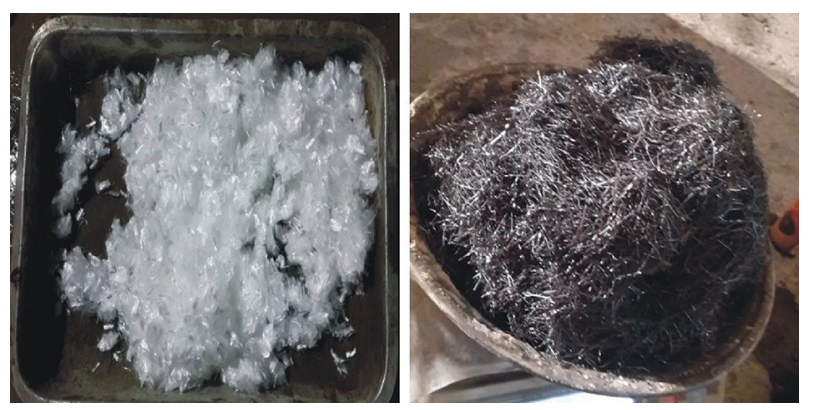

Fig. 1 PF and SF used in the present work

Table 4 Properties of superplasticizer used in concrete mixes

\begin{tabular}{lll}
\hline Sr. No & Description & Details \\
\hline 1 & The density of admixture at & Approximately $1.18 \mathrm{~kg} / \mathrm{lit}$ \\
& $25^{\circ} \mathrm{C}$ & \\
2 & $\mathrm{pH}$ value of NN & Approximately 8 \\
3 & The chloride content of NN & Nil (EN 934-2) \\
4 & Toxicity & Non-toxic \\
5 & Transportation & Non-hazardous \\
\hline
\end{tabular}

Polynapthalene based admixture namely Chemrite-NN was used as substantial water reducing agent at $0.6-2 \%$ by weight of cement complies with ASTM C494 [34] to increase the workability of freshly prepared FRC. Superplasticizers have many advantages such as increasing the workability and placing of concrete, early setting property, and minimum risk of segregation. Different properties of the superplasticizer used in the present study are listed in Table 4.

\subsection{Fabrication and testing of samples}

Twenty HFRC and one plain cement concrete (PCC) two-way slab specimens with dimensions of $900 \times 900 \times 100 \mathrm{~mm}$ were manufactured by using hybridization of four different volumetric fractions of SF $(0.7 \%$, $0.8 \%, 0.9 \%, 1 \%)$ and five that of PPF $(0.1 \%, 0.3 \%, 0.5 \%$, $0.7 \%, 0.9 \%$ ) to produce different combinations of fibers for each specimen. The ratios of fibers were selected to avoid the cracks and shrinks during the early stages [22]. The mix design of concrete was kept the same for all the specimens with ratios of 1:1.4:2.8:0.48 representing the 
ratios of cement, fine aggregates, coarse aggregates, and water to cement content, respectively (see Table 5).

Each mix design of samples is differentiated by using different volumetric ratios of hybrid fibers. Six steel bars of $10 \mathrm{~mm}$ diameter having a yield strength of $420 \mathrm{MPa}$ were used at equal spacing in both directions with a concrete cover of $20 \mathrm{~mm}$ on sides and $15 \mathrm{~mm}$ on top and bottom surfaces. In sample labeling, ' $S$ ' represents the slab specimen, the first numeric word after 'S' represents the ratio of $\mathrm{SF}$, and the second numeric word represents the ratio of PPF. During the casting of slab specimens, concrete cylinders for each mix design were also cast to determine the compressive strength of concrete with different fiber ratios. The average compressive strength values for each mix design are presented in Table 6.

Table 5 Quantities of concrete constituents

\begin{tabular}{ll}
\hline Material & Density $\left(\mathrm{Kg} / \mathrm{m}^{3}\right)$ \\
\hline Cement & 468.26 \\
Coarse aggregates & 1310.86 \\
Fine aggregates & 655.43 \\
Superplasticizer & $0.5 \%$ by volume \\
Water & 220.08 \\
Steel fiber & $0-1.0 \%$ by volume \\
PP fiber & $0-0.9 \%$ by volume \\
\hline
\end{tabular}

The sketch of the plan view and cross-sectional view of two-way slabs after preparing the sample for the experimental testing were shown in Fig. 2. The loading was applied to the center point of the slab using a load cell of $2000 \mathrm{kN}$ capacity. The specimens were $900 \times 900 \mathrm{~mm}$ in plan-view and their thickness was $100 \mathrm{~mm}$. Three strain gauges (at the shown locations) and one Linear Variable Differential Transformer (LVDT) at the center of the specimen were attached to measure the required parameters including vertical deflections and the strains in concrete and reinforcement. The load was applied at the central region of the two-way slabs using a load cell. The ends of the slabs were adjusted in such a way that one end performed as a roller support and the other end performed as a hinge support.

\section{Finite element modelling}

In the current research, the numerical work was performed using a general-purpose commercial program ABAQUS 6.14 [35]. The FEA model saves the cost and time required for experimentation. The concrete material and reinforcing bars were modeled as 3D stress and truss elements, respectively. A control numerical model was simulated using the experimental results of the load-deflection performance of control two-way slab specimen (S0.7-0.1).
Table 6 Test matrix of specimens and ratios of fibers

\begin{tabular}{|c|c|c|c|c|c|c|}
\hline Sr. No & Mix design & Sample Label & SF (\%) & PPF (\%) & $\begin{array}{l}\text { Total volumetric } \\
\text { ratio of fibers (\%) }\end{array}$ & $\begin{array}{l}\text { Compressive } \\
\text { strength (MPa) }\end{array}$ \\
\hline 1 & $\mathrm{~S} 2 \mathrm{M}-1$ & S0.0-0.0 & 0.0 & 0.0 & 0.0 & 23.51 \\
\hline 2 & $\mathrm{~S} 2 \mathrm{M}-2$ & S0.7-0.1 & 0.7 & 0.1 & 0.8 & 28.34 \\
\hline 3 & $\mathrm{~S} 2 \mathrm{M}-3$ & S0.7-0.3 & 0.7 & 0.3 & 1.0 & 31.91 \\
\hline 4 & $\mathrm{~S} 2 \mathrm{M}-4$ & S0.7-0.5 & 0.7 & 0.5 & 1.2 & 31.59 \\
\hline 5 & $\mathrm{~S} 2 \mathrm{M}-5$ & S0.7-0.7 & 0.7 & 0.7 & 1.4 & 25.08 \\
\hline 6 & $\mathrm{~S} 2 \mathrm{M}-6$ & S0.7-0.9 & 0.7 & 0.9 & 1.6 & 24.14 \\
\hline 7 & $\mathrm{~S} 2 \mathrm{M}-7$ & S0.8-0.1 & 0.8 & 0.1 & 0.9 & 29.3 \\
\hline 8 & $\mathrm{~S} 2 \mathrm{M}-8$ & S0.8-0.3 & 0.8 & 0.3 & 1.1 & 28.96 \\
\hline 9 & S2M-9 & S0.8-0.5 & 0.8 & 0.5 & 1.3 & 20.55 \\
\hline 10 & S2M-10 & S0.8-0.7 & 0.8 & 0.7 & 1.5 & 20.66 \\
\hline 11 & S2M-11 & S0.8-0.9 & 0.8 & 0.9 & 1.7 & 17.32 \\
\hline 12 & S2M-12 & S0.9-0.1 & 0.9 & 0.1 & 1.0 & 30.44 \\
\hline 13 & $\mathrm{~S} 2 \mathrm{M}-13$ & S0.9-0.3 & 0.9 & 0.3 & 1.2 & 26.35 \\
\hline 14 & S2M-14 & S0.9-0.5 & 0.9 & 0.5 & 1.4 & 24.26 \\
\hline 15 & S2M-15 & S0.9-0.7 & 0.9 & 0.7 & 1.6 & 29.62 \\
\hline 16 & S2M-16 & S0.9-0.9 & 0.9 & 0.9 & 1.8 & 22.61 \\
\hline 17 & $\mathrm{~S} 2 \mathrm{M}-17$ & S1.0-0.1 & 1.0 & 0.1 & 1.1 & 28.87 \\
\hline 18 & $\mathrm{~S} 2 \mathrm{M}-18$ & S1.0-0.3 & 1.0 & 0.3 & 1.3 & 20.71 \\
\hline 19 & S2M-19 & S1.0-0.5 & 1.0 & 0.5 & 1.5 & 24.68 \\
\hline 20 & S2M-20 & S1.0-0.7 & 1.0 & 0.7 & 1.7 & 26.9 \\
\hline 21 & S2M-21 & S1.0-0.9 & 1.0 & 0.9 & 1.9 & 18.32 \\
\hline
\end{tabular}


Fig. 2 Schematic plan view and the cross-sectional view of testing of two-way slab

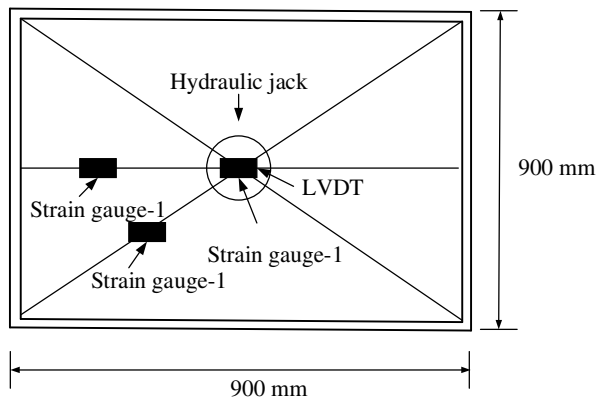

(a)

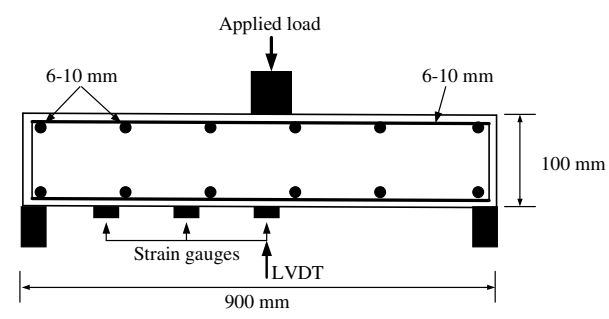

(b)

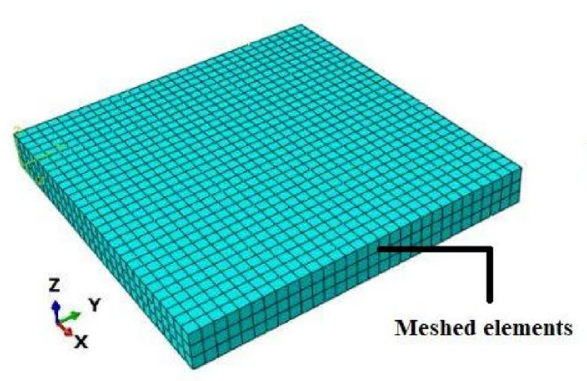

(a)

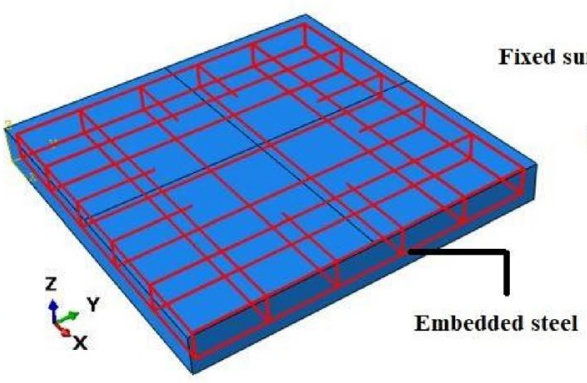

(b)

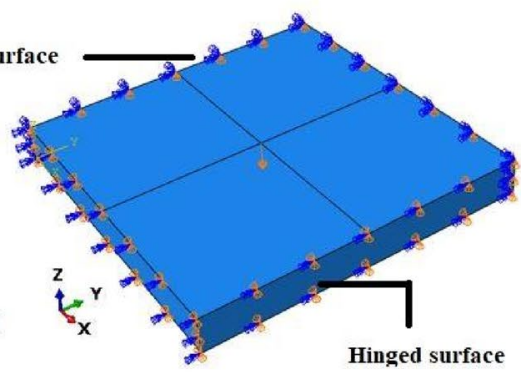

(c)

Fig. 3 Geometry and boundary conditions of the finite element model of the two-way slab (a) meshing (b) embedded region constraint (c) boundary conditions

Two sides of specimens were kept fixed in all directions and the other two were kept hinged to resist reactions and deflections in vertical and lateral directions. A point load was applied to the center of the two-way slab specimens using the displacement control method as represented in Fig. 3. The behavior of concrete and steel bars were simulated using the concrete damaged plasticity (CDP) model and bilinear elastoplastic model, respectively. For the validation of the control numerical model, an extensive calibration work was performed by considering the sensitivity of different material and geometric parameters of the specimen.

\subsection{Materials simulations}

The accuracy of the constitutive FEA model will be more if the boundary conditions and materials properties are defined accurately which is a complex task. The accurate simulation of the complex nonlinear behavior of concrete material under triaxial loading is a challenging task. The experimental stress-strain curves of each specimen with different quantities of SF and PPF were used for the definition of concrete behavior taken from [19]. For the definition of elastic behavior of concrete, two parameters are required in ABAQUS; one is elastic modulus and the second is the Poison's ratio. Elastic modulus of concrete was

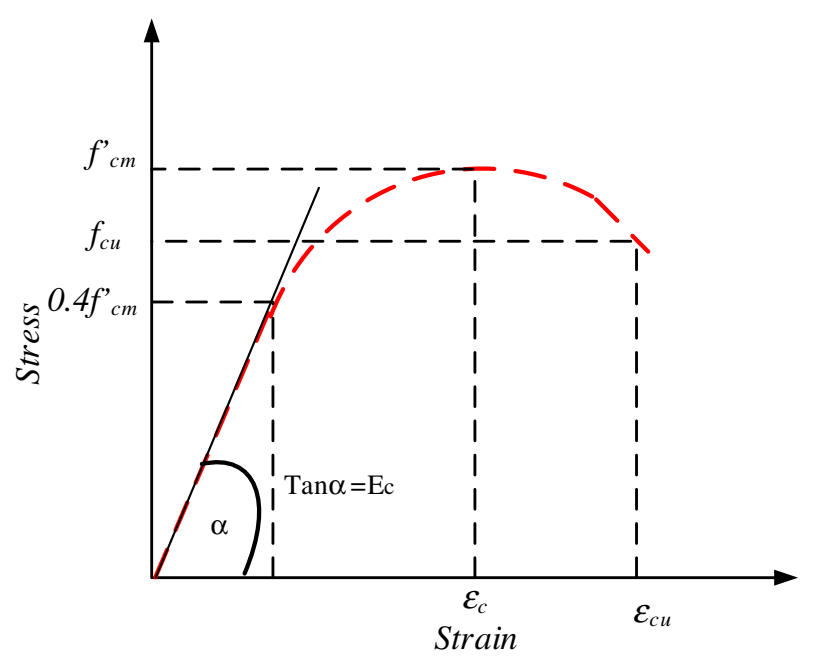

Fig. 4 Stress-strain performance of RC structures according to Euro code 2

taken as $4700 \sqrt{f_{c}^{\prime}}$ and the Poison's ratio was taken as 0.2 up to $0.4 f_{c}^{\prime}$ [36] (see Fig. 4). The CDP model in ABAQUS can accurately predict the nonlinearity and complexity of plain and reinforced concrete $[37,38]$ and therefore, this model was used in the current work for the simulations of the 
inelastic behavior of reinforced concrete (RC). The parameters for plastic behavior were calibrated using different values to achieve the results closer to experimental predictions. For the simulations of compressive damaging behavior of concrete, Eq. (1) and Eq. (2) were utilized for the calculations of compressive strains $\left(\varepsilon_{c, 1}\right.$ and $\left.\varepsilon_{c u,}\right)$ and Eq. (3) was used for the calculations of compressive stress $\left(f_{c}^{\prime}\right)$ of RC [39].

$\varepsilon_{c, 1}=0.0014\left[2-e^{-0.024 f_{c m}}-e^{-0.140 f_{c m}}\right]$

$\varepsilon_{c u, 1}=0.004-0.0011\left[1-e^{-0.0215 f_{c m}}\right]$

$f_{c}^{\prime}=f_{c m} \frac{k \eta-\eta^{2}}{1+(k-2) \eta}$

where $k=1.05 E_{c m} \frac{\varepsilon_{c, 1}}{f_{c m}}$ and $\eta=\frac{\varepsilon_{c}}{\varepsilon_{c, 1}}$ where $f_{c m}$ is the maximum compressive strength of reinforced concrete. To define the tensile behavior of concrete is essential for the flexural members because of the tensile stresses on the bottom side of the slabs. The stress-strain model of concrete under tension should include the strain hardening and softening behavior and interaction between steel bars and concrete material. The tension stiffening model used in the present research has been represented in Fig. 5. The ultimate tensile stress $\left(f_{t}^{\prime}\right)$ was calculated using Eq. (4) as proposed by [39].

$f_{t}^{\prime}=0.33 \sqrt{f_{c}^{\prime}}(M P a)$

The steel reinforcement having $420 \mathrm{MPa}$ yield strength was used in the present research. The steel reinforcement was simulated as truss elements available in ABAQUS. The elastic behavior was defined by Young's modulus of

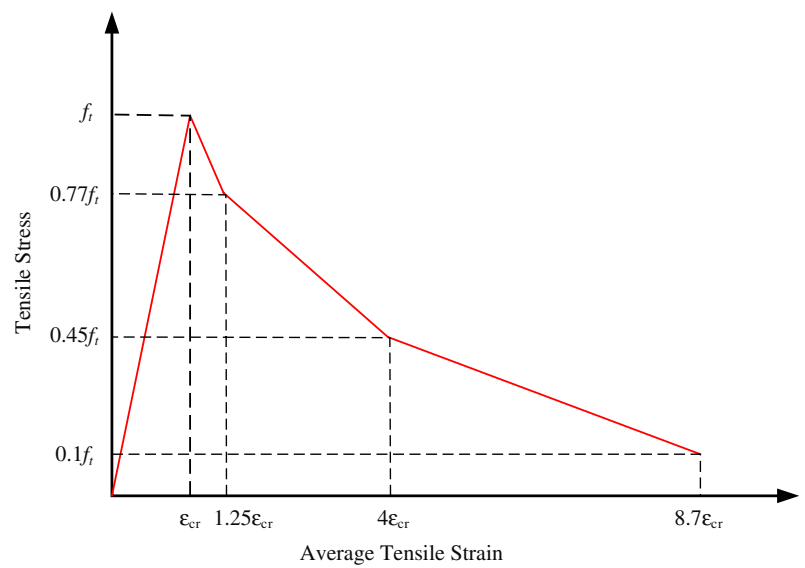

Fig. 5 Tensile model of concrete
$200 \mathrm{GPa}$ and Poison's ratio of 0.3 . The simulation of plastic behavior of steel bars was performed by considering elastoplastic material with the bilinear performance of the stress-strain model having a strain hardening ratio of $0.01 \%$ for the second linear line [40] as shown in Fig. 6 .

\subsection{Calibration and validation of control model}

The control FE model was calibrated and validated using the experimental results of the load-deflection behavior of S0.7-0.1. Different material parameters of concrete in the plastic region such as the angle of dilation stresses ratio, viscosity parameter, and shape factor parameter were calibrated using different values to achieve optimum accuracy as represented in Fig. 7. The different values of dilation angle used for the calibration were $45,42,39,36$, 33 and 30 degrees and that of viscosity parameter were $0.064,0.053,0.042,0.031,0.020$ and 0.009 . The governing parameter during the calibration process was found to be the viscosity parameter. An increase of $136 \%$ occurred in the loading capacity when this parameter increased from 0.009 to 0.64 . Similarly, the different values were calibrated for stress ratio and shape factor of concrete yielding. A negligible effect was observed due to the variation of stress ratio and shape factor of concrete. However, the viscosity parameter of 0.02 , dilation angle of 42 degrees, shape factor of 0.667 , and a stress ratio of 1.16 gave the best results as compared with experimental predictions.

The sensitivity analysis due to variation of element types of concrete and reinforcement was also performed. All the types of 3D-stress elements of concrete material available in the ABAQUS library were examined and similarly, the effects of different truss elements of 3D-planer reinforcement bars were also observed, represented in Fig. 7. It was observed that 3-dimensional 8 node brick elements with reduced integration (C3D8R) for concrete as recommend by [40] and 3-dimensional 2 node truss

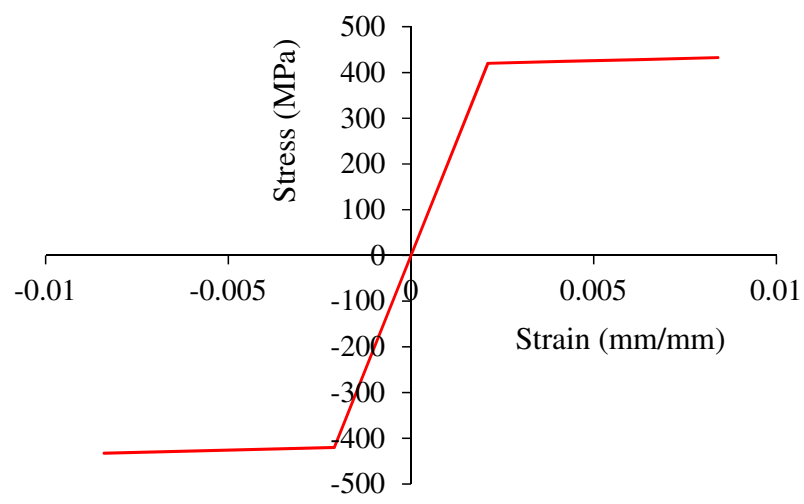

Fig. 6 Bilinear behavior of reinforcement 

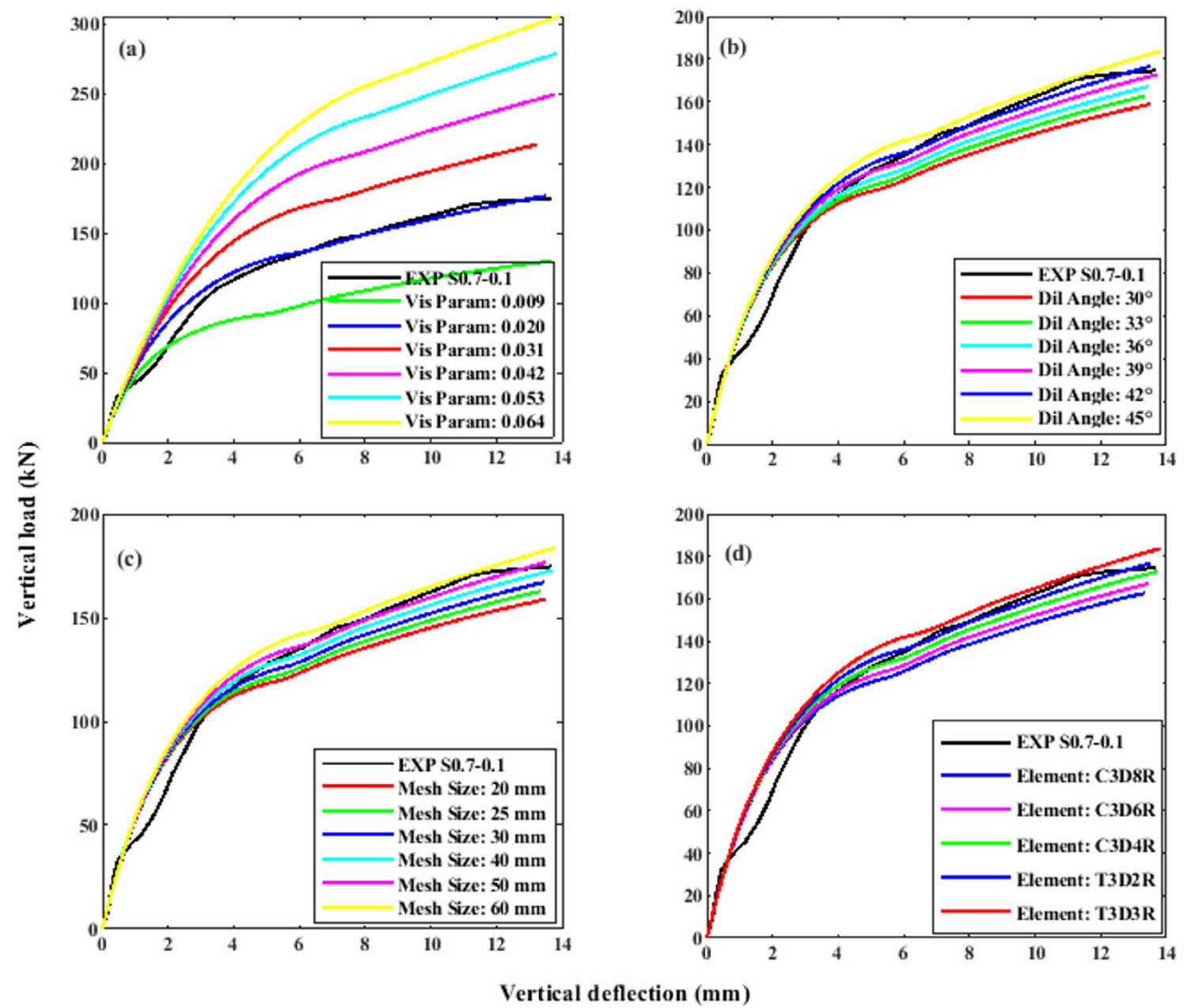

Fig. 7 Sensitivity analysis of load-deflection curve due to a Viscosity parameter $\mathbf{b}$ Dilation angle $\mathbf{c}$ Mesh size $\mathbf{d}$ element types of concrete and steel reinforcement

elements with reduced integration (T3D2R) for steel bars gave the close results in comparison with that of experiments.

The sensitivity analysis due to the size of elements of concrete and steel bars was observed by studying the mesh sizes of $60,50,40,30,25$, and $20 \mathrm{~mm}$, respectively. The effect of using different mesh sizes on the load-deflection behavior of a two-way slab control specimen was represented in Fig. 7. In linear FEA, the accuracy of outputs usually increases by decreasing the mesh size, but it does not hold for NLFEA [40]. The mesh size should not be small enough to increase the time of analysis for the computer. After an extensive calibration for various element sizes, it was observed that the mesh size of $30 \mathrm{~mm}$ gave close agreement with the experiments, and hence, this size was selected for the further analysis of remaining specimens and parametric study.

\section{Experimental results and discussions}

\subsection{Workability of mixes}

It is widely accepted that controlling the workability of fiber reinforced concrete is cumbersome due to the presence of fiber which decreases workability than ordinary mix. To increase the workability of the concrete mix, the superplasticizer named Chemrite NN was used. For measuring the workability of FRC, a slump cone test according to ASTM C143/C143M-15a [41] was performed for each batch of concrete. The workability of concrete was controlled in the range of $25-75 \mathrm{~mm}$ of slump cone as represented by Fig. 8 .

It is obvious that the control mix has maximum workability and the minimum slump was noted for mix having 
Fig. 8 Slump values of different concrete mixes

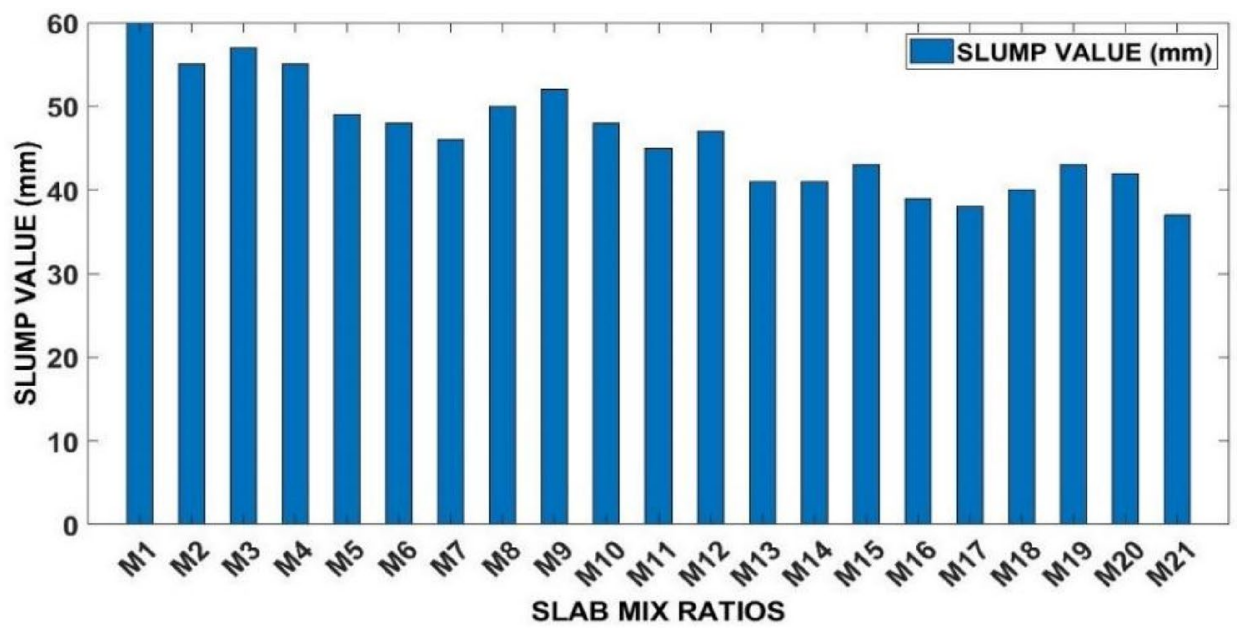

steel fibers with a volume fraction of $1 \%$ of concrete and $0.1 \%$ of polypropylene fiber. Mixes with steel fibers are much stiffer than mixes with polypropylene fibers due to the accumulation of water around steel fibers resulting in a reduction of free water in the mix. In the case of mix having only polypropylene fibers, workability was close to that of the control mix due to the softness of polypropylene fibers. Accumulation of water around fibers was quite less as seen in the case of steel fibers.

\subsection{Flexural testing of slabs}

The flexural behavior of two-way slabs was determined using different volumetric ratios of steel fibers and polypropylene fibers, a center point loading test was performed to check the first cracking load and the value of ultimate failure load. The deflection in slabs was measured using LVDT placed at the center of the slab, where maximum deflection was supposed to have occurred. Three strain gauges were also placed at different locations to measure strain response on the bottom fiber of the specimens. Strain gauges were connected to a Whishay strain indicator and recorder $\mathrm{P} 3$ box. The deflection and three strains were recorded. The schematic diagram for the arrangement of measuring devices is given in Fig. 2 and the experimental testing was presented in Fig. 9. The complete structural and flexural analysis was performed using data recorded during testing. The experimental results in terms of initial and final cracks loads and corresponding deflections were presented in Table 7.

\subsection{Load pattern in HFRC slab}

During the application of load with the help of loading jack on slabs, the appearance of cracks in flexure was observed, which indicates the yielding zone. These values indicate that the specimen is starting to fail. The comparison of these cracks showed that each specimen has the separate cracking patterns with different combinations of hybrid fibers. This clearly shows that both fibers complement each other to produce the best results. These fibers need to be in perfect ratio to give maximum strength. Figure 10
Fig. 9 Flexural testing of specimen a Top view of the specimen b Bottom view with LVDT

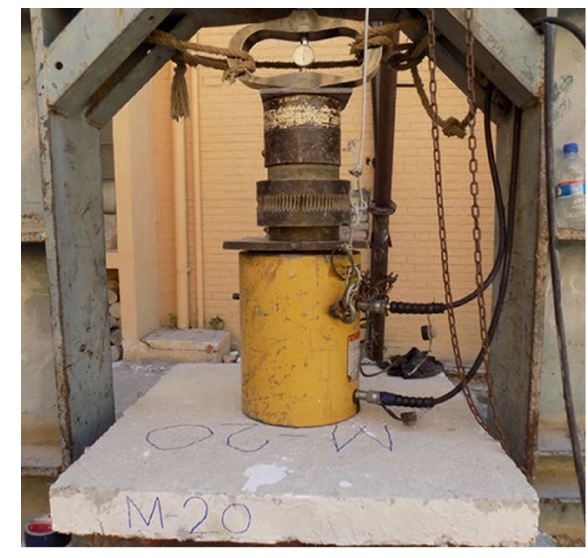

(a)

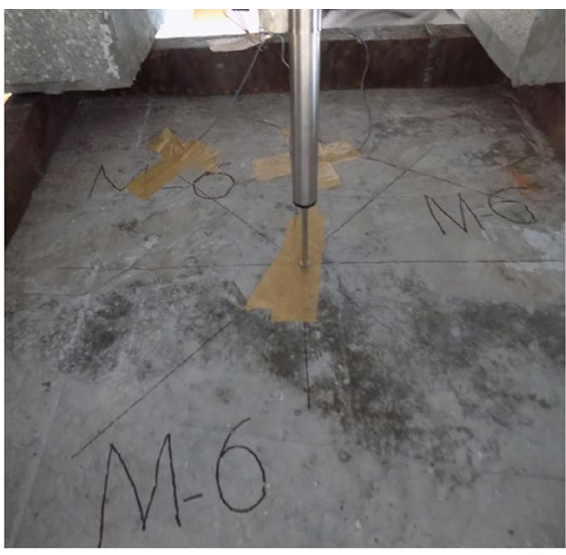

(b) 
Table 7 Experimental flexural testing results of HFRC twoway slabs

\begin{tabular}{|c|c|c|c|c|c|}
\hline Mix ratio & Label & $\begin{array}{l}\text { First crack } \\
\text { load (kN) }\end{array}$ & Ultimate load (kN) & $\begin{array}{l}\text { First crack deflec- } \\
\text { tion }(\mathrm{mm})\end{array}$ & $\begin{array}{l}\text { Ultimate } \\
\text { deflection } \\
(\mathrm{mm})\end{array}$ \\
\hline S2M-1 & S0.0-0.0 & 35.84 & 159.53 & 2.832 & 11.03 \\
\hline S2M-2 & S0.7-0.1 & 44.8 & 174.62 & 1.692 & 13.67 \\
\hline $\mathrm{S} 2 \mathrm{M}-3$ & S0.7-0.3 & 67.2 & 192.43 & 1.118 & 9.31 \\
\hline S2M-4 & S0.7-0.5 & 89.6 & 189.76 & 2.734 & 7.97 \\
\hline S2M-5 & S0.7-0.7 & 53.76 & 201.53 & 1.481 & 10.91 \\
\hline S2M-6 & S0.7-0.9 & 53.76 & 209.05 & 2.089 & 11.85 \\
\hline S2M-7 & S0.8-0.1 & 53.76 & 171.31 & 1.285 & 9.55 \\
\hline S2M-8 & S0.8-0.3 & 53.76 & 201.96 & 1.745 & 14.04 \\
\hline S2M-9 & S0.8-0.5 & 67.2 & 221.21 & 2.768 & 15.12 \\
\hline S2M-10 & S0.8-0.7 & 40.32 & 190.34 & 2.468 & 14.51 \\
\hline S2M-11 & S0.8-0.9 & 67.2 & 154.76 & 1.694 & 8.98 \\
\hline S2M-12 & S0.9-0.1 & 112 & 223.93 & 4.101 & 15.42 \\
\hline S2M-13 & S0.9-0.3 & 67.2 & 176.52 & 1.952 & 10.56 \\
\hline S2M-14 & S0.9-0.5 & 67.2 & 206.26 & 2.054 & 11.15 \\
\hline S2M-15 & S0.9-0.7 & 89.6 & 179.91 & 2.624 & 13.2 \\
\hline S2M-16 & S0.9-0.9 & 44.8 & 197.06 & 1.026 & 10.64 \\
\hline S2M-17 & S1.0-0.1 & 89.6 & 211.7 & 2.824 & 12.53 \\
\hline S2M-18 & S1.0-0.3 & 89.6 & 208.11 & 2.52 & 12.09 \\
\hline S2M-19 & S1.0-0.5 & 80.64 & 150.93 & 2.77 & 8.22 \\
\hline S2M-20 & S1.0-0.7 & 67.2 & 167.63 & 1.928 & 10.14 \\
\hline S2M-21 & S1.0-0.9 & 67.2 & 111.18 & 1.527 & 6.67 \\
\hline
\end{tabular}

Comparison of load carrying capacity at first crack level

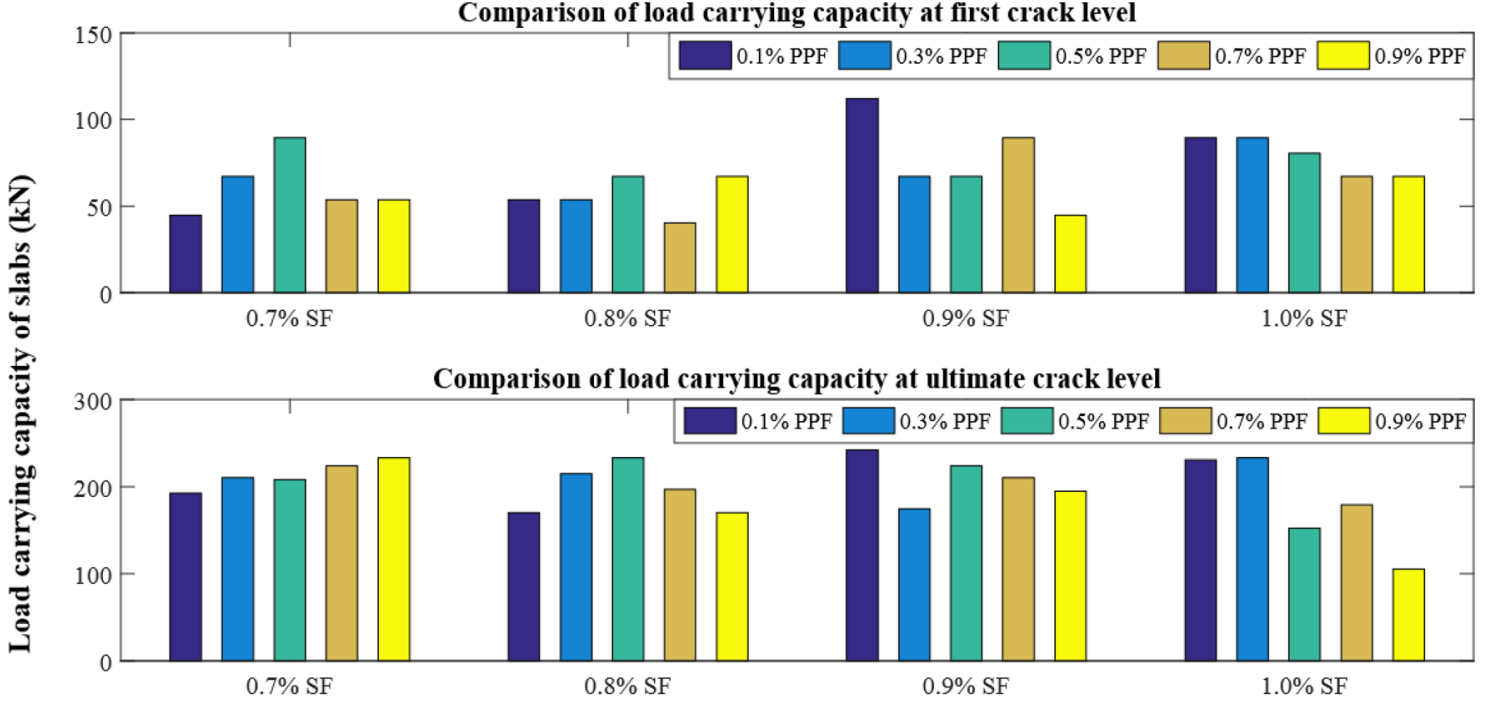

Different ratios of steel fibres

Fig. 10 First crack loads and ultimate loads of all slab specimens

shows the comparison of first crack loads for the different volumetric ratios of steel and polypropylene fibers.

A comparison of the values shows that using both fibers increases the strength of concrete concerning the control specimen. The maximum resistance against the first crack was endured by the S0.9-0.1. It carried the load of $112 \mathrm{kN}$ before the first crack appeared. The control specimen cracked at the loading of $35.84 \mathrm{kN}$. The first crack strength of specimen $50.9-0.1$ has a $213 \%$ increase. The initial crack values of S0.7-0.5, S0.8-0.5, and S1.0-0.3 
were $89.6 \mathrm{kN}, 67.2 \mathrm{kN}$, and $89.6 \mathrm{kN}$, respectively which shows a $150 \%, 88 \%$, and $150 \%$ increase, respectively. The combination of $0.9 \%$ SF and $0.1 \%$ PPF performed in a well manner showing the maximum loading capacity. This may be ascribed to a good bridging effect of fibers at this percentage. At the ultimate loading stage, the deflection was increased considerably but the loadcarrying capacity was continuously decreasing. The ultimate capacity for each type of slab was observed as represented in Fig. 10.

Almost all the slabs were failed in flexure and the cracks also extended up to the outer edges of the slabs. The increase in loading was observed from 5.56 to $50.0 \%$ except for slabs S1.0-0.5 and S1.0-0.9. In these samples, the reduction in ultimate strength was observed to be 5.56 and $34.74 \%$, respectively. This is because of the fluctuation of both the fibers, balling action, improper mixing, and thus resulting in bleeding of the concrete mix. The results are consistent with the first crack loading.

The values in the above graph clearly show that each group follows the same trend. The load-carrying capacity increasing up to a particular ratio and after that value starts to decrease. It follows the same trend in every group. The maximum resistance against the ultimate loading was ensured by S0.9-0.1. It carried the load of $223.93 \mathrm{kN}$ before completely failing. The control specimen S0.0-0.0 was fully cracked at the loading of $159.53 \mathrm{kN}$. The ultimate strength of specimen S0.9-0.1 has a $40.36 \%$ increase. The values of S0.7-0.5, S0.8-0.5, and S1.0-0.3 were $189.76 \mathrm{kN}, 221.21 \mathrm{kN}$, and $208.11 \mathrm{kN}$, respectively which shows $18.94 \%, 38.66 \%$, and $30.45 \%$ increase, respectively. These combinations of the hybrid fibers portrayed a good performance in terms of loading strength due to an efficient bridging effect of fibers.

\subsection{Deflection pattern in HFRC slab}

With the application of load, the deflection in the two-way slab was observed. The deflection in the slab was measured with the help of LVDT. One LVDT was placed at the bottom center of the slab. During testing of concrete slabs, the deflection was noted just after the appearance of the first crack for each type of slab and presented in Fig. 11. The slab was examined at each load increment to check the propagation of cracks and it was noted that the crack was initiated from the middle of the slab and then towards the outer periphery in a regular manner. Maximum deflection at first crack load was achieved by the specimen S0.90.1 which is $44.81 \%$ more than the control specimen S0.00.0. The deflection at first crack observed in the control specimen was $2.832 \mathrm{~mm}$. With the addition of steel fibers, the stiffness of the section increased but with the addition of polypropylene fibers an increase in the slab deflection was observed as compared with the control model (S0.00.0 ). The increase in the deflection caused an increase in the strain absorption of each specimen which means an increase in the modulus of resilience and modulus of toughness which are the two basic flexural properties of concrete. Ultimate deflection is defined as the deflection at which the specimen reached its maximum load when there is no further load-carrying capacity in the slab. Ultimate deflections of all slabs were presented in Fig. 11.

The deflection at the first crack of the slab S0.9-0.1 was higher than that of all other slabs and also when specimens

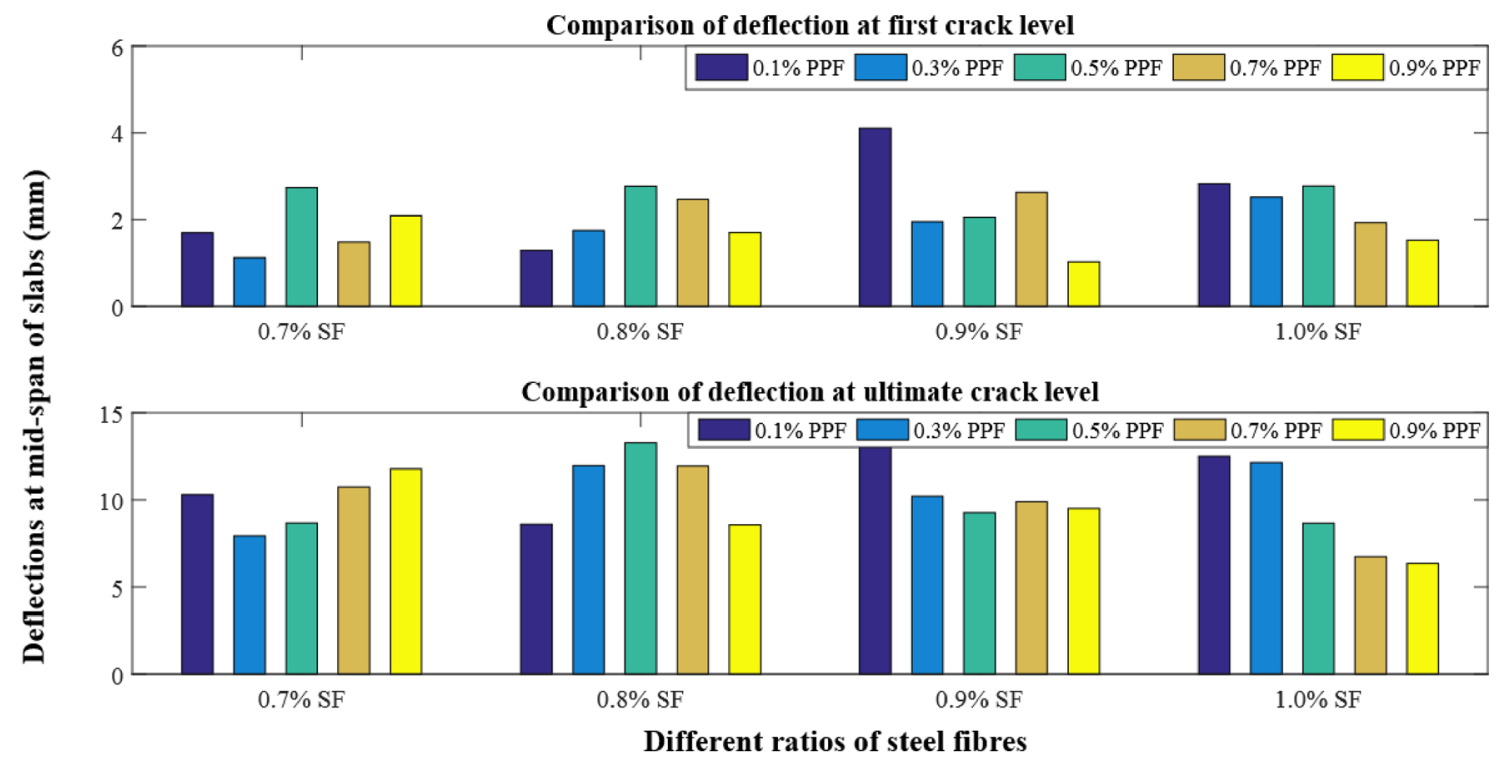

Fig. 11 Deflections at ultimate loads 
reached their ultimate loading capacity, the specimen S0.9-0.1 having fibers contents of $0.9 \% \mathrm{SF}+0.1 \% \mathrm{PPF}$ by volume of concrete showed maximum deflection with comparison to other specimens. This is because slab S0.90.1 has maximum loading capacity. Maximum deflection at ultimate load was achieved by S0.9-0.1 specimen which is $15.42 \mathrm{~mm}$ and is $39.80 \%$ more than the control specimen S0.0-0.0. The deflection observed in the control specimen was $11.03 \mathrm{~mm}$. In conclusion, the application of flexural loading caused a significant amount of deflection which was measured using LVDT. The increase in deflection was $44.81 \%$ for $50.9-0.1$ at first crack load whereas $39.80 \%$ for ultimate load in comparison with the control specimen. Load carrying capacity increased up to an optimum value of $213 \%$ for the first crack loading condition and $40.36 \%$ for the ultimate loading condition for S0.9-0.1 slab as compared to the control slab.

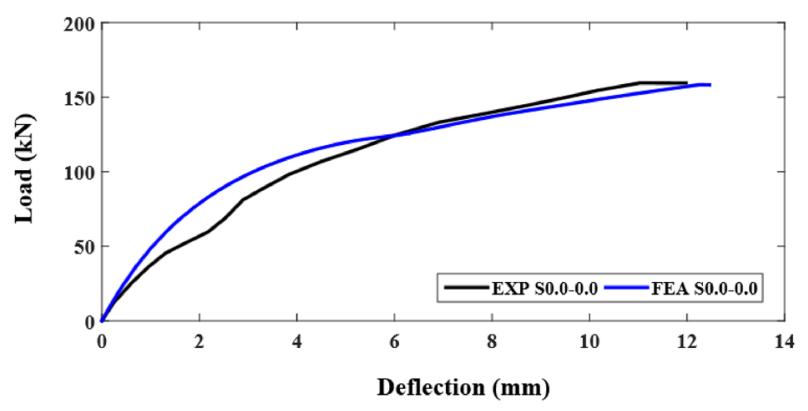

Fig. 12 Load-deflection performance of control model for experimental and numerical results
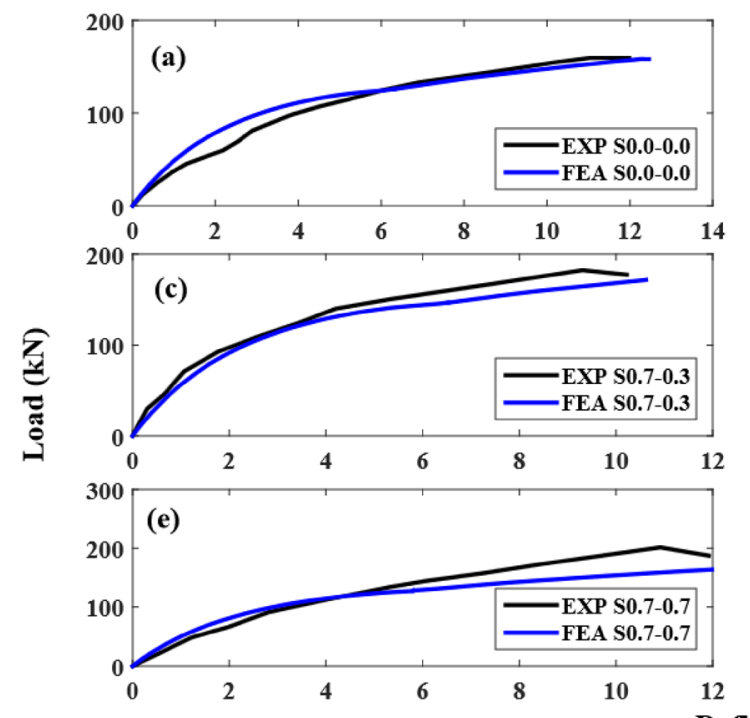

\section{Finite element results}

\subsection{Control specimen}

The load-deflection curve for the control specimen was shown in Fig. 12. It can be observed that the discrepancy between experimental and numerical predictions is 2.89 and $4.24 \%$ for slab capacity and corresponding deflection, respectively. This discrepancy may be associated with the perfect bond assumed between reinforcement and concrete elements in the form of a 'tie' constraint in ABAQUS. Moreover, these minor discrepancies may be ascribed to the small imprecisions and imprecise results due to the differences between the actual testing experimental conditions such as initial geometric imperfections, different boundary conditions, varying strength of steel bars, the strength of concrete material, manufacturing faults of the specimens, the accuracy of the testing instruments and the conditions assumed in the FEA modeling. However, the proposed constitutive finite element model gives a close agreement between experiments and numerical results.

\subsection{Load-deflection curves}

To measure deflection at mid-span of the slab, one LVDT was placed below the center of the two-way slab. The deflection was noted for every increment of loading using a load cell positioned above the slabs. The load-deflection curves for all the slabs were shown in Figs. $13,14,15$ and 16 . It was observed that the initials,
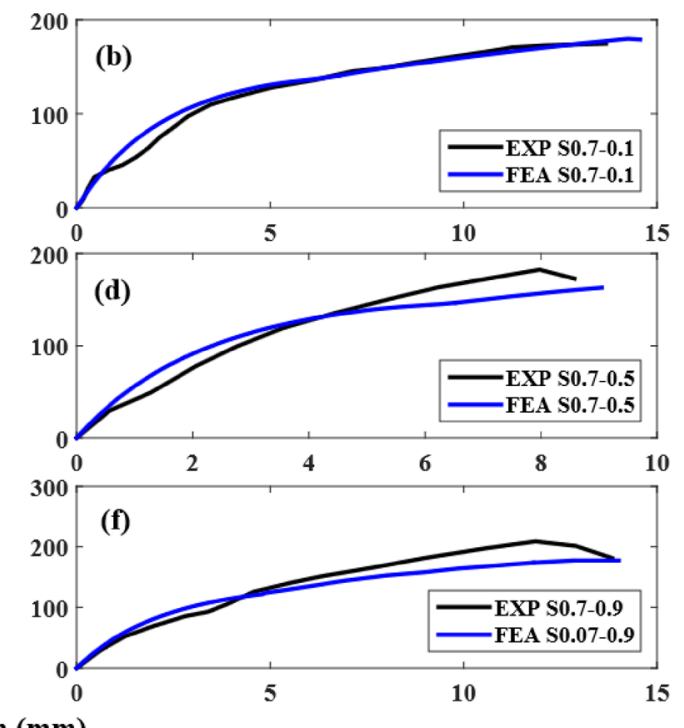

Fig. 13 Experimental and numerical load-deflection curves for two-way slabs with a plain concrete and $0.7 \%$ SF along with combination of b $0.1 \%$ PPF c $0.3 \%$ PPF d $0.5 \%$ PPF e $0.7 \%$ PPF f $0.9 \%$ PPF 

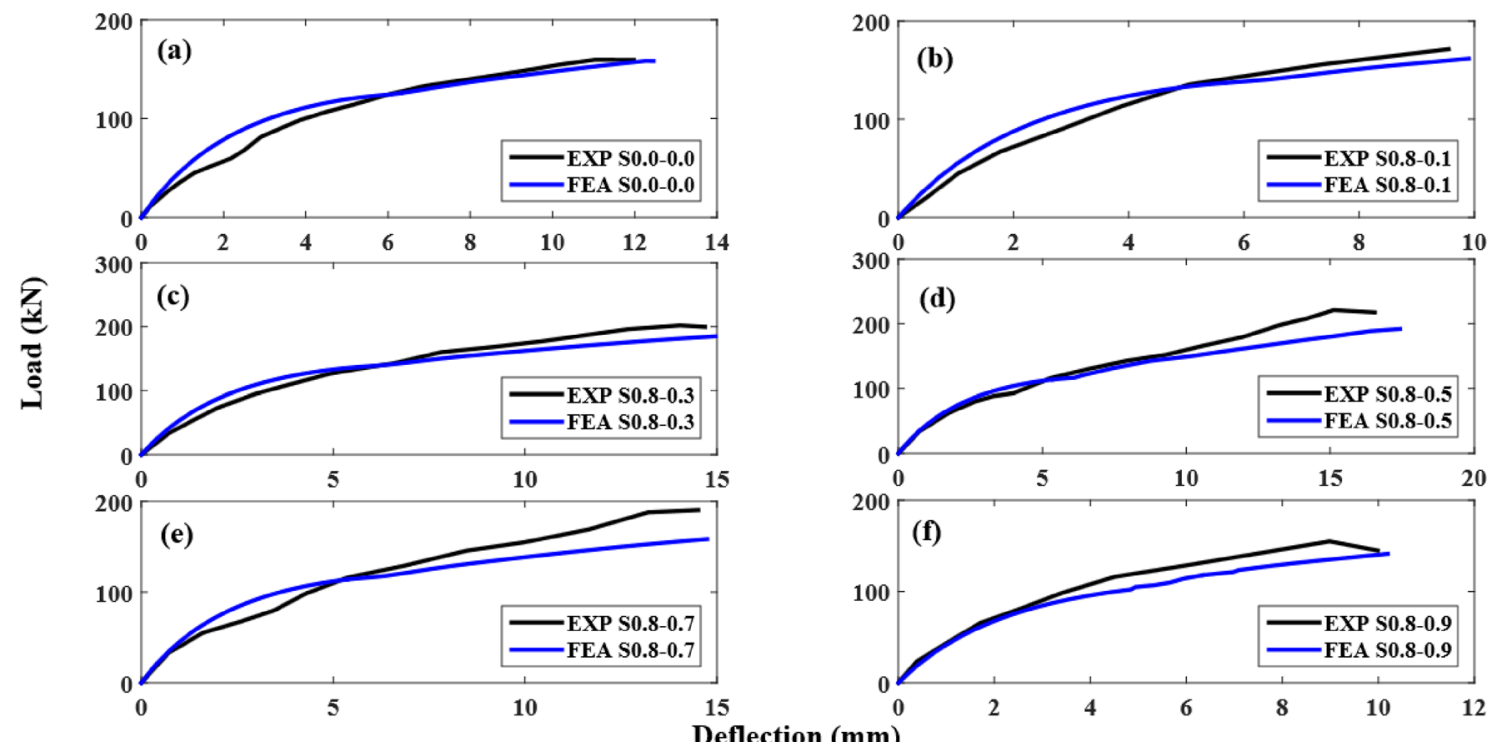

Fig. 14 Experimental and numerical load-deflection curves for two-way slabs with a plain concrete and $0.8 \%$ SF along with combination of b $0.1 \%$ PPF c $0.3 \%$ PPF d $0.5 \%$ PPF e $0.7 \%$ PPF f $0.9 \%$ PPF
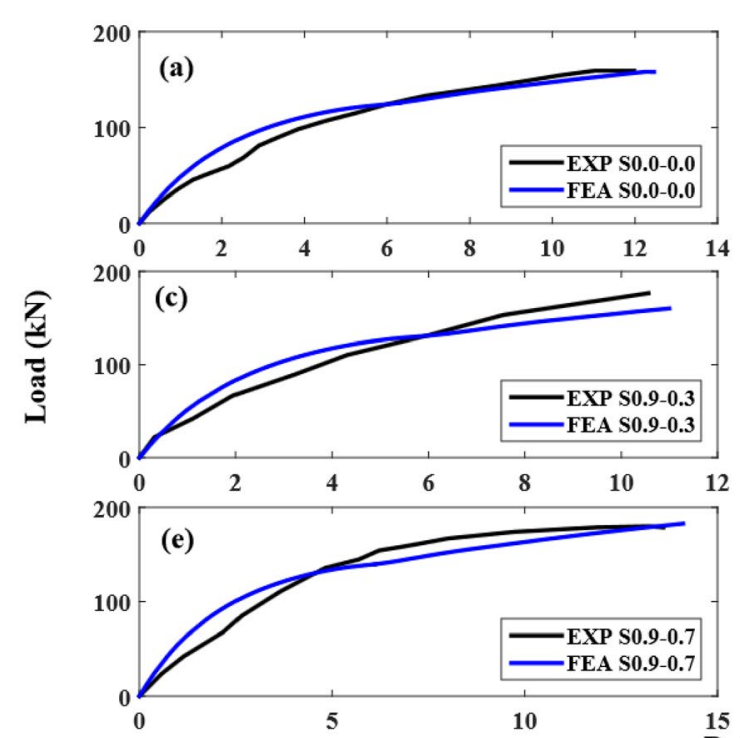
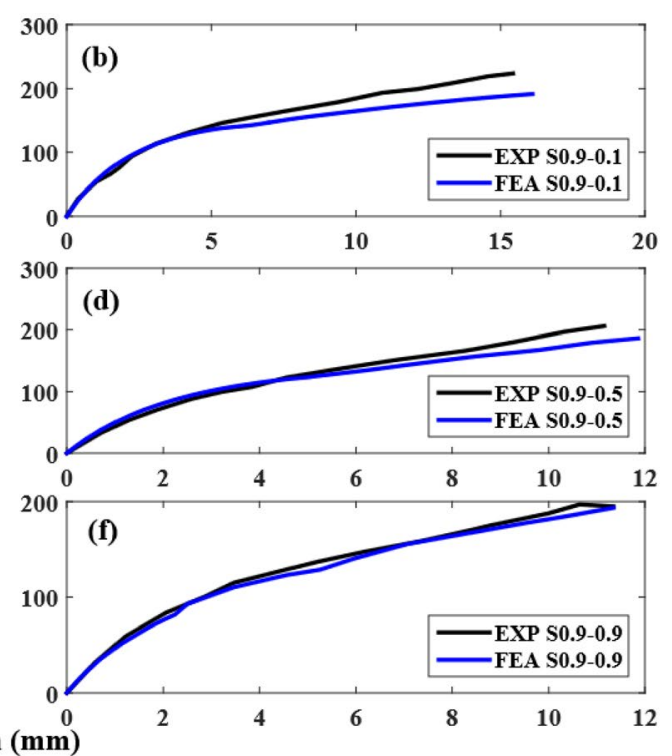

Fig. 15 Experimental and numerical load-deflection curves for two-way slabs with a Plain concrete and 0.9\% SF along with combination of b $0.1 \%$ PPF c $0.3 \%$ PPF d $0.5 \%$ PPF e $0.7 \%$ PPF f $0.9 \%$ PPF

as well as the ultimate load-carrying capacity of slab S0.9-0.1, were quiet high compare to control specimen S0.0-0.0. But it can also be observed that at initial stages both curves (experimental curve and FEA curve) are almost overlapping each other but after the elastic state, the loading capacity was changed abruptly. This is due to the reason that the fiber-reinforced concrete improved the post elastic properties of structural members [42]. It was worth mentioning that deflection at the ultimate failure of the control specimen was low in comparison with that of S0.9-0.1.

Figure 13 reports the complete load-deflection curves for the specimens with $0.7 \% \mathrm{SF}$. The load-deflection curves of S1.0-0.5 and S1.0-0.9 were plotted with load at the vertical axis and deflection at the horizontal axis to compare behavior with that of the control specimen. The curves for S1.0-0.5 and S1.0-0.9 have a sudden failure at the ultimate load as there was a little gap between the elastic 

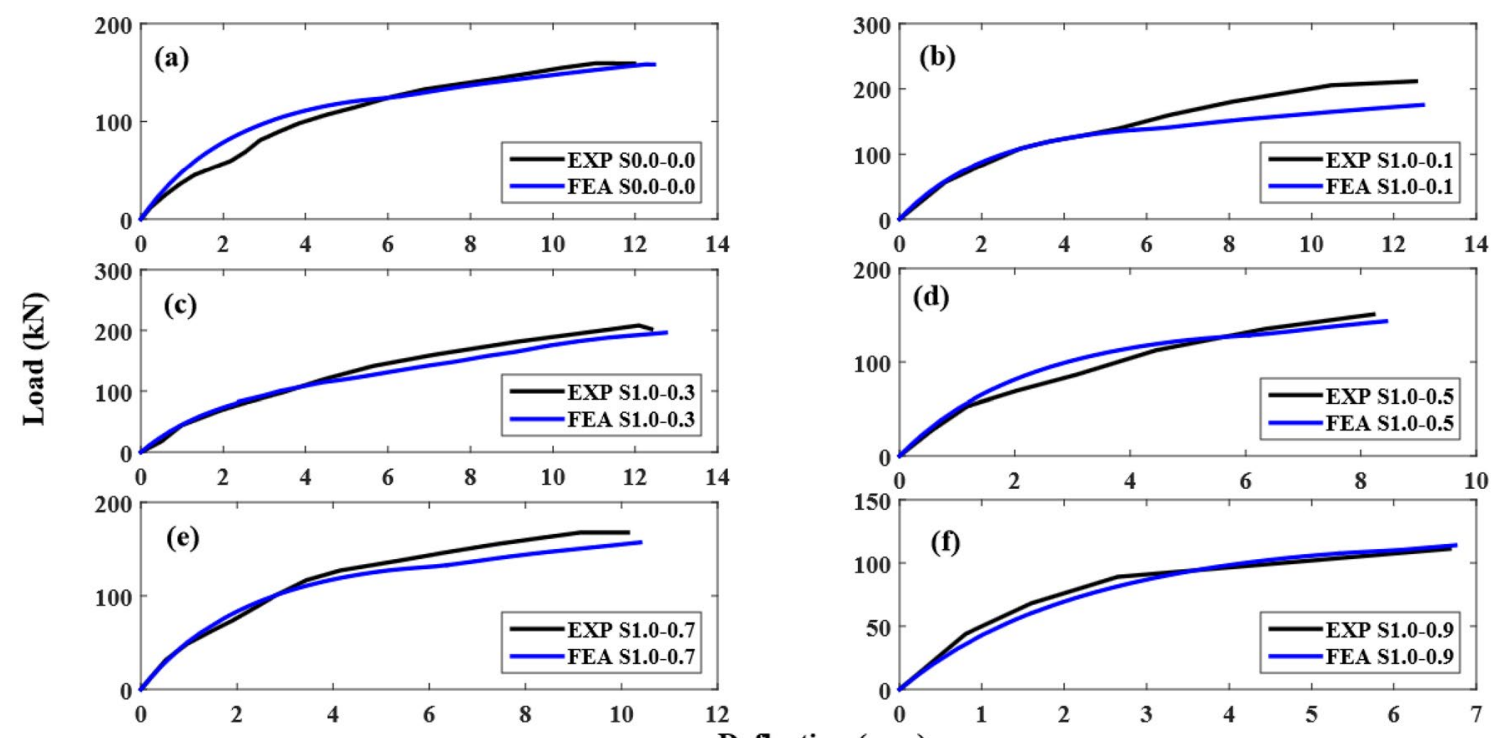

Deflection (mm)

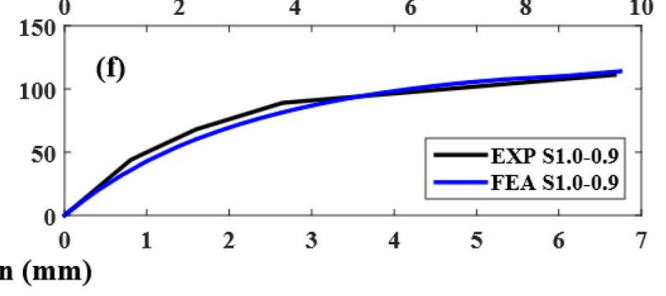

Fig. 16 Experimental and numerical load-deflection curves for two-way slabs with a Plain concrete and $1.0 \%$ SF along with combination of b $0.1 \%$ PPF c $0.3 \%$ PPF d $0.5 \%$ PPF e $0.7 \%$ PPF f $0.9 \%$ PPF

limit stage and the ultimate failure stage. Although slabs S1.0-0.5 and S1.0-0.9 showed a sufficient increase in load at the initial stage as it reached a final cracking load before the control sample. This was because of high steel \& polypropylene fiber contents along with flocculation of both fibers, balling action, improper mixing, and thus resulting in bleeding of the concrete mix.

Also, in the same trend load-deflection curves for peak values of S0.7-0.5, S0.8-0.5 and S1.0-0.3 were plotted with load at the vertical axis and deflection at the horizontal axis to compare behavior with that of the control specimen. It was observed that both the initial and ultimate load-carrying capacity of slabs S0.7-0.5, S0.8-0.5, and S1.0-0.3 was quiet high compare to the control specimen. But it can also be observed that at initial stages all curves are almost overlapping each other but after the elastic state load-carrying capacity was changed suddenly. Such behavior is due to the reason that the fiber-reinforced concrete improves the post elastic properties of structural members [42]. It was worth mentioning that deflection at the ultimate failure of the control specimen was low with comparison to that S0.7-0.5, S0.8-0.5, and S1.0-0.3.

For the finite element study of two-way slabs, the experimental load-deflection curves were converted to backbone curves to examine the peak loads and their corresponding vertical deflections. After validation of control FEM, it was used for the further analysis of remaining slab specimens to investigate the applicability and implementation of the structural response of two-way slabs systems. The comparison of experimental and FEA predicted load-deflection behaviors of specimens with $0.7 \% \mathrm{Sf}$ were presented in Fig. 13. It was observed that the discrepancies among experimental and FEA observations for the ultimate capacities of the RC slab systems with plain concrete and $0.7 \%$ SF were $0.75 \%, 2.89 \%, 10.84 \%, 10.44 \%, 18.79 \%$, $15.05 \%$, for S0.0-0.0, S0.7-0.1, S0.7-0.3, S0.7-0.5, S0.7-0.7 and S0.7-0.9, respectively. Similarly, the discrepancies for deflection at peak loads were $11.06 \%, 4.24 \%, 14.07 \%$, $13.43 \%, 9.81 \%$ and $8.44 \%$, respectively. The average percentage difference among the finite element predictions and experimental measurements of slabs with $0.7 \%$ SF was $9.79 \%$ and $10.17 \%$ for ultimate capacity and corresponding vertical deflection, respectively. The performance of the finite element load-deflection curve in the elastic region was relatively better but in the inelastic region, there were some discrepancies. These minor discrepancies may be ascribed to the reasons due to deviations between experimental and numerical boundary conditions, material properties variations, instrumentation and loading conditions, manufacturing faults, and assumptions made during finite element simulations.

Figure 14 represents the structural response of slab specimens with plain concrete and $0.8 \%$ steel fibers along with $0.1 \%, 0.3 \%, 0.5 \%, 0.7 \%$ and $0.9 \%$ PPF, respectively. The percentage deviations observed from the comparisons of numerical predictions and experiments were $5.60 \%, 8.48 \%, 14.75 \%, 16.81 \%$, and $10.18 \%$ for specimens S0.8-0.1, S0.8-0.3, S0.8-0.5, S0.8-0.7, and S0.8-0.9, respectively. Similarly, the discrepancies for deflections were $3.66 \%, 6.48 \%, 8.40 \%, 1.52 \%$ and $8.80 \%$, respectively. The average percentage difference was observed to be 11.16 and $577 \%$ for an ultimate capacity of two-way slabs and 
their corresponding vertical deflections, respectively. This shows that the proposed constitutive FEA model gave better predictions for specimens with $0.8 \% \mathrm{SF}$ as compared with that of $0.7 \%$ SF.

The FEA prediction for the ultimate loads was usually less than the experimental loads after approximately $100 \mathrm{kN}$. This may be due to the reason that the equations used for the prediction of the stress-strain behavior of HFRC material were initially developed for the plain concrete, but in the current research, they were used for the HFRC. As concerned with the predictions of the FEA model against experimental measurements for two-way slabs with $0.9 \%$ SF, they were represented in Fig. 15. The discrepancies of peak load results were $14.45 \%, 9.27 \%, 9.61 \%$, $1.54 \%$ and $1.79 \%$ and that of deflections were $4.41 \%$, $4.07 \%, 6.37 \%, 6.82 \%$ and $6.58 \%$ for the specimens $50.9-$ 0.1, S0.9-0.3, S0.9-0.5, S0.9-0.7 and S0.9-0.9, respectively. On average, the percentage discrepancy for specimens with $0.9 \%$ SF was 7.33 and $5.65 \%$ for loading capacity and deflections, respectively.

The minimum error from numerical modeling was observed for the specimens reinforced with steel fibers of $1.0 \%$ quantity by the total volume of the specimen as shown in Fig. 16. The proposed model presented the discrepancies of $17.09 \%, 5.69 \%, 4.88 \%, 6.28 \%$ and $2.56 \%$ for peak capacities and $1.36 \%, 5.38 \%, 2.68 \%, 2.47 \%$ and $1.05 \%$ for deflections of slab specimens $\$ 1.0-0.1, \mathrm{~S} 1.0-0.3$, S1.0-0.5, S1.0-0.7 and S1.0-0.9, respectively. The average percentage error between the experiments and numerical work was $7.30 \%$ and 2.585 for load and deflection, respectively.

The numerical model predictions and experimental testing results for peak loads and corresponding vertical deflections at peak loads were represented in Figs. 17 and 18 , respectively. It can be observed that the predictions of the finite element were underestimated by $17.33 \%$ as compared with experimental measurements. This may be associated with the reason that the assumptions made in the FEA model for the bond-slip behavior between steel bars and concrete material were not perfect for the degrees of freedom (DOF) to be transferred from 3D truss elements to the 3D brick elements of concrete. Moreover, the definitions of compression and tension damage behaviors of concrete may also be ascribed to the reason of discrepancies because for flexural loading the accurate definition of these parameters is very important.

It can be observed from Fig. 18 that the predictions of the finite element were overestimated the vertical deflections by $19.5 \%$ as compared with experimental measurements. This discrepancy may be due to the assumptions of a perfect bond between steel bars and concrete material which made the slabs stiffer in numerical modeling. But in general, the proposed FE model showed consistent predictions in comparison with experimental measurements and can be used for the further analysis and parametric study of two-way RC slab.

\subsection{Crack patterns}

The crack patterns were studied during the testing of all specimens. With the use of polypropylene, there was a very large increase in the deflection obtained by specimens as compared to the control specimen. According to experimental results, it can be said that with the use of more polypropylene more elastic behavior of concrete is obtained. But the force of attraction between particles of concrete remains the same hence if larger deflection is obtained it will some time break the bond between particles of concrete hence producing a fissure plane that will cause the spalling of concrete. With
Fig. 17 Experimental and numerical peak loads for all specimens

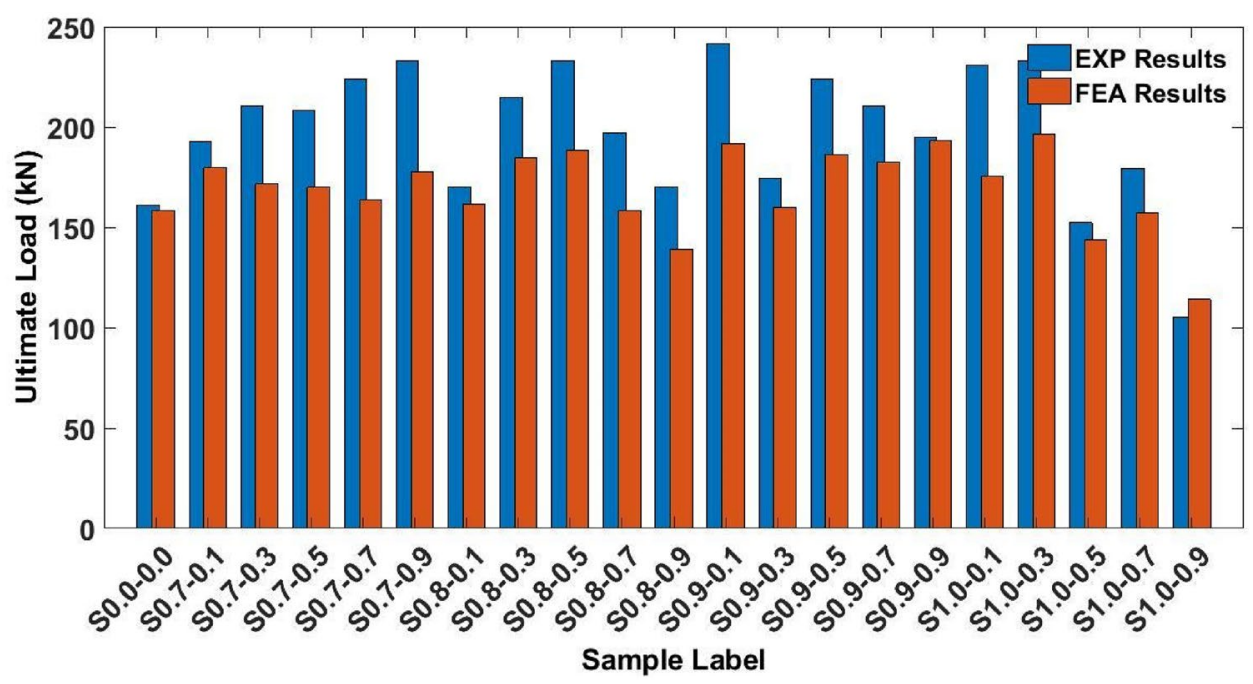


Fig. 18 Experimental and numerical deflections at peak loads

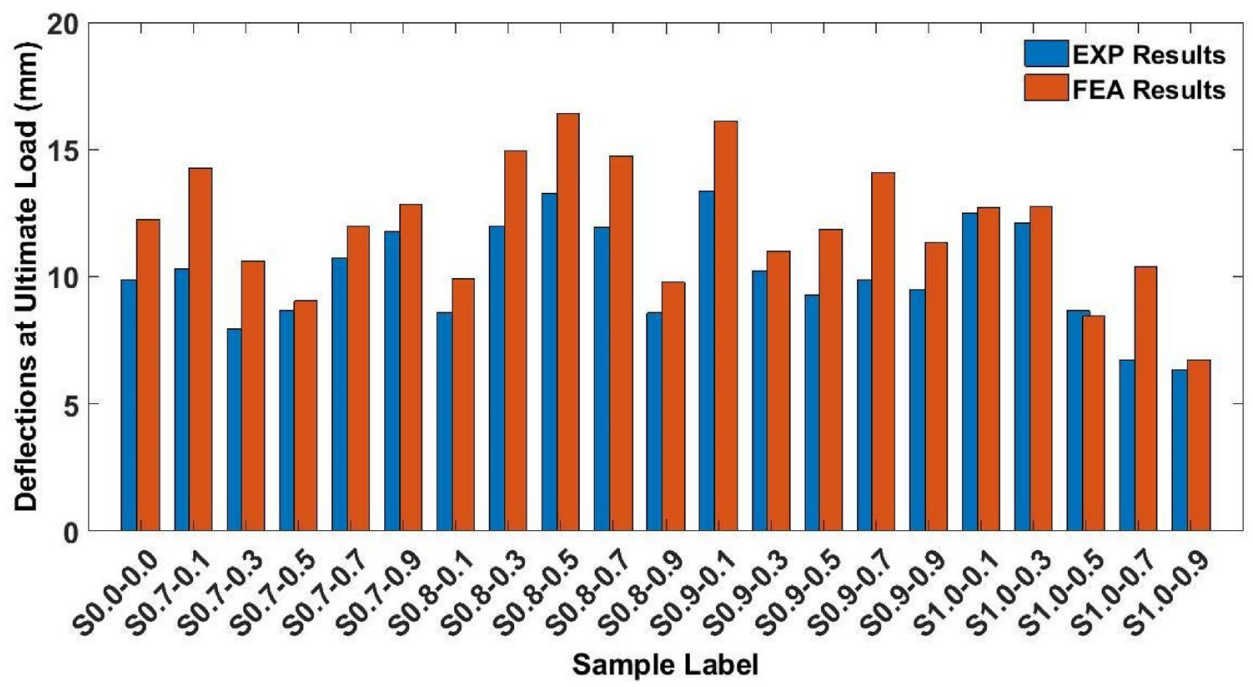

the use of steel fibers, it can be stopped up to some extent. The use of steel fibers helps in the transmission of the load over the fissure plane and which helps the specimen to transmit load over the entire span. But this can only be obtained with the use of a particular blend where both fibers complement each other and a greater loading, as well as deflection, is achieved.

Mostly, the cracks were developed on the tension side of the slabs in diagonal directions and the number of cracks increased slowly up to the collapse stages. The crack study was also performed using the FEA model as presented in Fig. 19, 20, 21, 22. The FEA crack patterns were represented using Max. Positive Principal plastic strains as reported in the previous studies [41, 42]. Moreover, FEA cracks patterns can also be represented using the stress limits of concrete material. When the stress of the compressive strength of concrete material increases from its limit, the cracking of concrete occurs at that location causing the yielding of steel reinforcement. It can be observed that the proposed FEA model accurately captured the crack patterns of the two-way slab specimens. The crack patterns obtained from FEA modeling represents that the proposed model predicted the concrete crushing accurately. In most of the slabs, the cracking was started at the yield line of the slab due to the center point loading flexural test and increased gradually up to the failure of the specimen. All the specimens presented the two peak behaviors; one from the start of loading up to the elastic limit of the curve for the first crack load; the second peak was obtained at the ultimate load-carrying capacity of specimens with the rupture of concrete material on the bottom side of specimens.

\section{Parametric study}

The sensitivity of various parameters was examined using the proposed FEA model. Those parameters were main reinforcement ratio $\left(\rho_{l}\right)$, concrete cover (cc) and concrete strength in compression $\left(f_{c}^{\prime}\right)$. The sensitivity of these parameters was studied in 3D plots as shown in Fig. 23.

\subsection{Effect of main reinforcement $\left(\rho_{l}\right)$}

The effect of main reinforcement $\left(\rho_{l}\right)$ was presented in Fig. 23. It was observed that by increasing the $\rho_{l}$, there was an increase in the load-carrying capacity of the HFRC twoway slab. When the $\rho$, was increased from 1.13 to $5.48 \%$, an increase of $51.21 \%$ occurred in capacity with the increase of concrete strength $\left(f_{c}^{\prime}\right)$ from 10 to $50 \mathrm{~N} / \mathrm{mm}^{2}$. Similarly, by enhancing the same amount of reinforcement, the increase in vertical deflection of mid-span of the slab, a maximum increase of $45.29 \%$ occurred. When we increase the $\rho_{l}$ along with the increase of concrete cover (cc), the capacity of the slab increases by $101.24 \%$, and the vertical deflection increase by $37.47 \%$. 

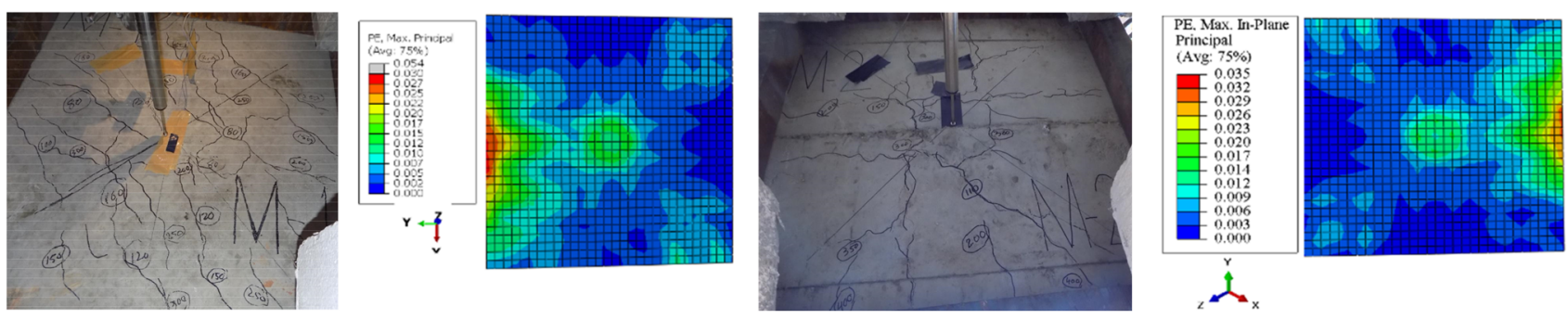

S2M-1

S2M-2
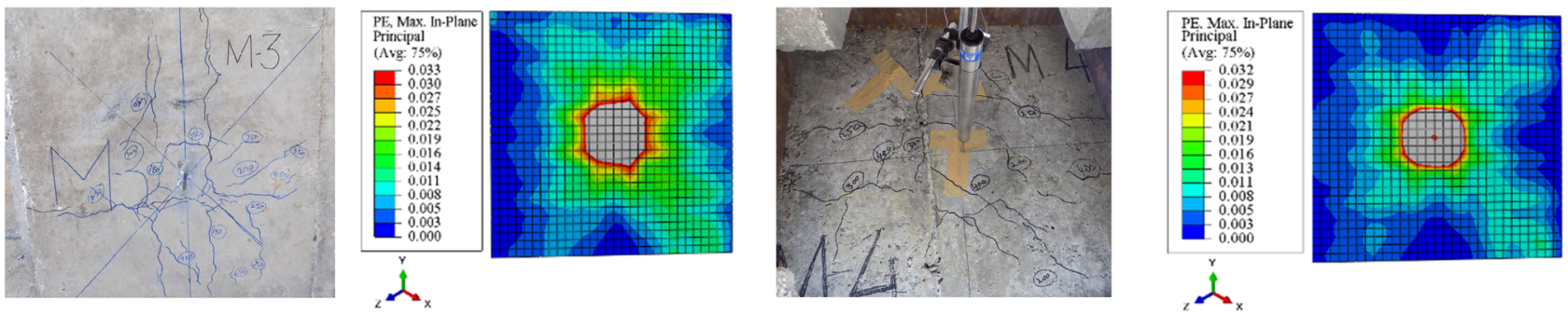

S2M-3

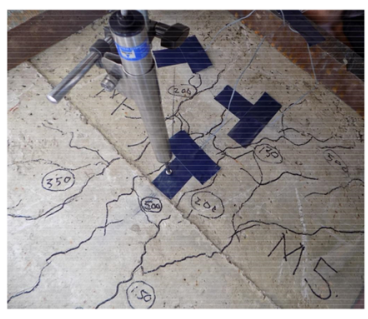

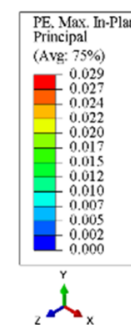

S2M-5
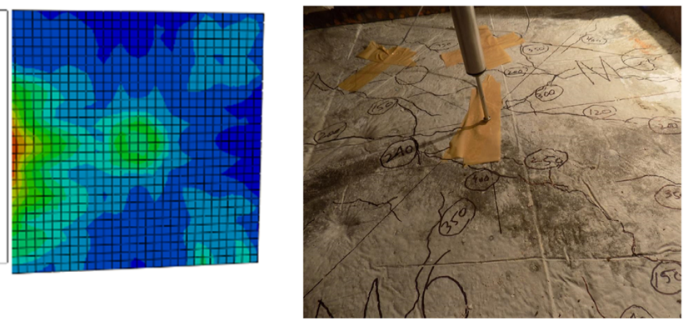

$\mathrm{S} 2 \mathrm{M}-4$

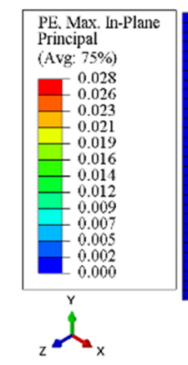

S2M-6

Fig. 19 Experimental and numerical crack patterns of two-way plain concrete and HFRC slabs with $0.7 \%$ steel fibers

\subsection{Effect of concrete cover}

The effect of the concrete cover was opposite to that of the main reinforcement. By increasing the concrete cover with the increase of $\rho_{l}$, there is a maximum decrease of 40.46 and $41.83 \%$ for loading capacity and corresponding vertical mid-span deflection, respectively as represented in Fig. 23. Similarly, by increasing the concrete cover with the increase of $f_{c}^{\prime}$, there is a maximum decrease of 170.52 and $51.84 \%$ for loading capacity and corresponding vertical mid-span deflection, respectively.

\subsection{Effect of concrete strength $\left(f_{c}^{\prime}\right)$}

The effect of concrete strength was dominant on the loadcarrying capacity and vertical deflection of HFRC two-way slabs. When the $f_{c}^{\prime}$ was enhanced from 10 to $50 \mathrm{MPa}$, the increase of $145.73 \%$ was observed in loading capacity and the increase of $47.49 \%$ was observed in corresponding vertical deflection with the increase of $\rho_{l}$ as presented in Fig. 23. Similarly, while increasing the 'cc', the optimum effect of $f_{c}^{\prime}$ increase $f_{c}^{\prime}$ was $170.92 \%$ for vertical capacity and $51.84 \%$ for deflection. 

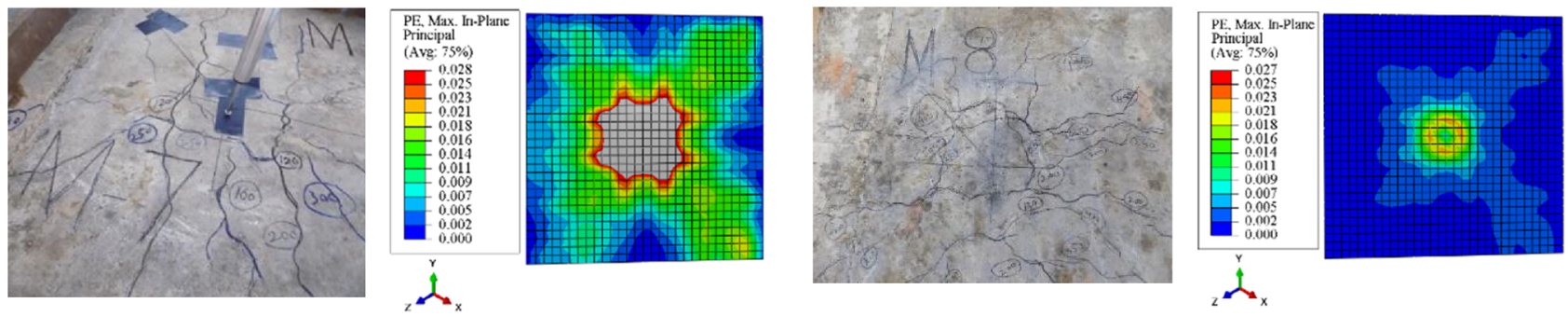

S2M-7
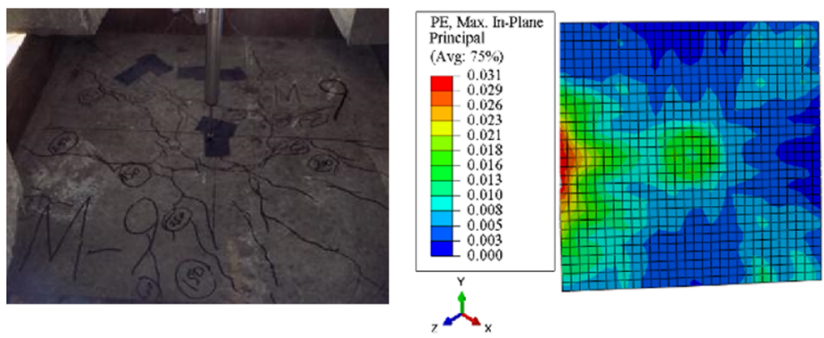

S2M-9

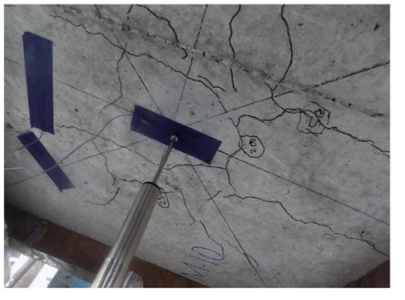

S2M-8
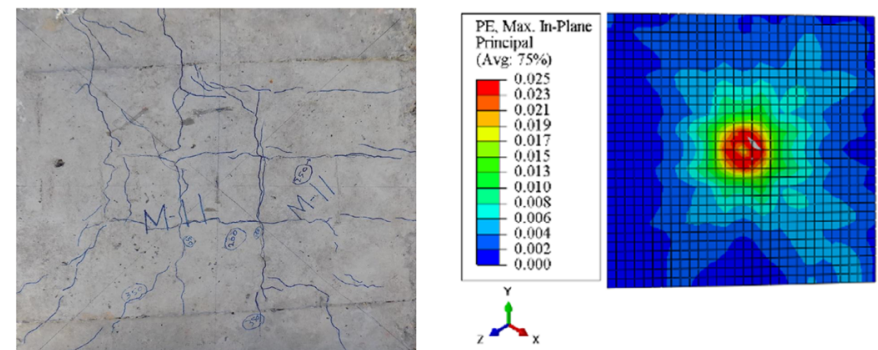

S2M-11

Fig. 20 Experimental and numerical crack patterns of two-way HFRC slabs with $0.8 \%$ steel fibers

\section{Conclusions}

This investigation aims to examine the load-deflation behavior of HFRC two-way slabs. A total of 21 specimens were fabricated and tested to failure under flexural loading. The following conclusions were drawn from the current research work:

1. The increase in the quantity of hybrid fibers in concrete reduces the workability of concrete and shows a stiffer nature of concrete in two-way slabs.

2. The load-carrying capacity of the HFRC two-way slab was increased up to a maximum percentage of $213 \%$ for the first crack loading condition and $40.36 \%$ for the ultimate loading condition for the S0.9-0.1 slab as compared to the control specimen having zero fibers.
The maximum increase in deflection was $44.81 \%$ at first crack load whereas $39.80 \%$ at the ultimate load for 50.9-0.1 in comparison with the control specimen.

3. The maximum load-carrying capacity of two-way slabs was achieved up to $213 \%$ for first crack loading and up to $45 \%$ for ultimate loading. In the case of slabs S1.0-0.5 and S1.0-0.9, the increase in first crack loading observed from 113 and $88 \%$, respectively but in the case of ultimate loading, the load-carrying capacity of S1.0-0.5 and S1.0-0.9 decreased by 6 and $27.61 \%$, respectively as compared to control specimen (S0.00.0 ). This decrease in ultimate load-carrying capacity is due to increased quantities of both types of fibers and improper mixing of fibers in concrete due to their large quantity. 

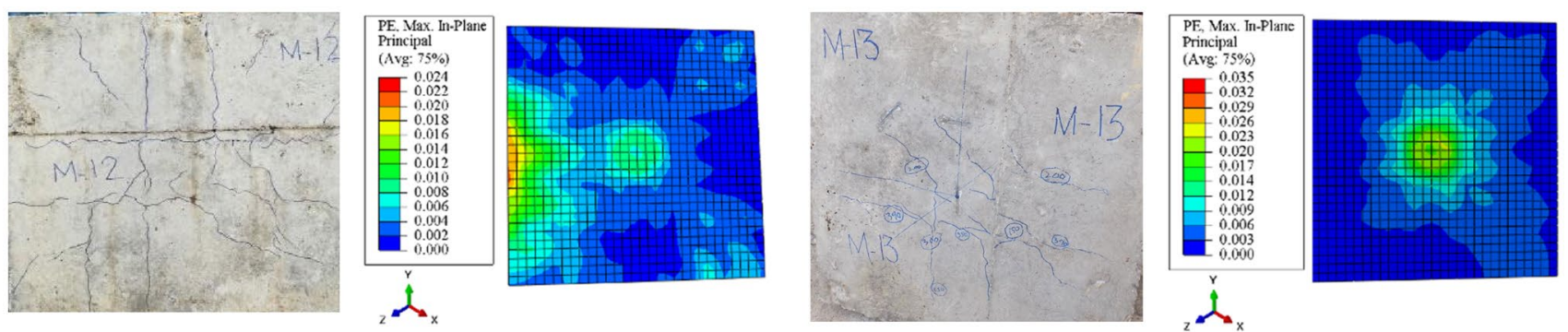

S2M-12
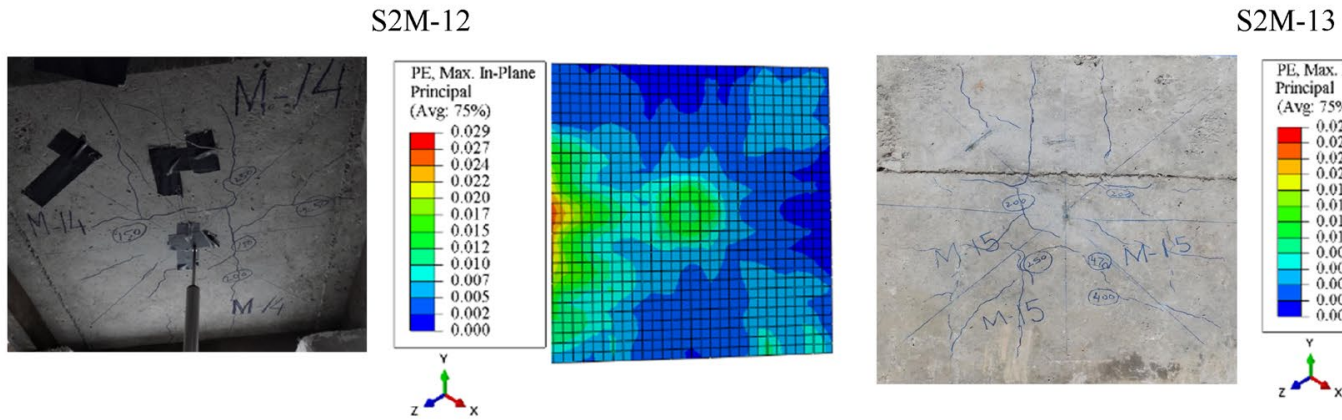

S2M-14

S2M-15
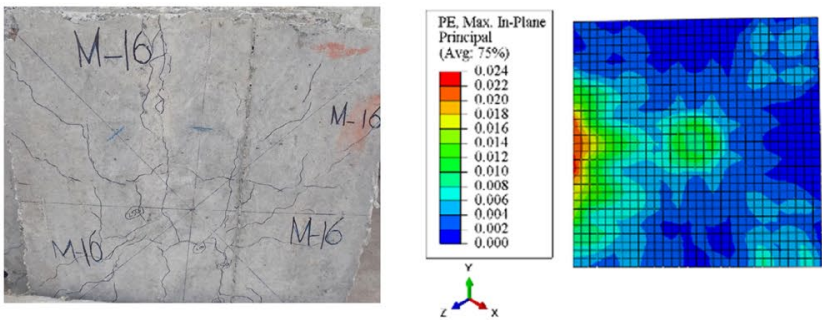

S2M-16

Fig. 21 Experimental and numerical crack patterns of two-way HFRC slabs with $0.9 \%$ steel fibers

4. The maximum loading capacity and corresponding vertical mid-span deflection of HFRC two-way slabs were achieved by using a volumetric combination of $0.9 \%$ SF and $0.1 \%$ PPF. The good results of the cracking patterns and failure process of slabs were obtained from the suggested FEA model.

5. The parametric study concludes that there is an increase in load-carrying capacity and ductility with the increase of concrete strength and the main reinforcement ratio, while the effect of concrete cover is the opposite.

6. The average percentage discrepancies among the experimental and FEA results were 8.94 and $6.24 \%$ for load and deflection, respectively. Therefore, it can be said that the proposed constitutive FEA model pre- dicted the behavior of the HFRC two-way slab, accurately and it can be helpful for the structural engineers in the analysis and design of two-way slab systems with hybrid fibers reinforcement.

The authors recommend the further investigation of two-way slabs reinforced completely with either fiber reinforced polymers (FRPs) reinforcement or a combination of both steel and FRP reinforcement. Furthermore, the structural performance of two-way slab should be investigated by using recycled aggregates concrete because the recycled aggregates concrete has been proved to report higher ductility as compared with the natural coarse aggregate concrete. 

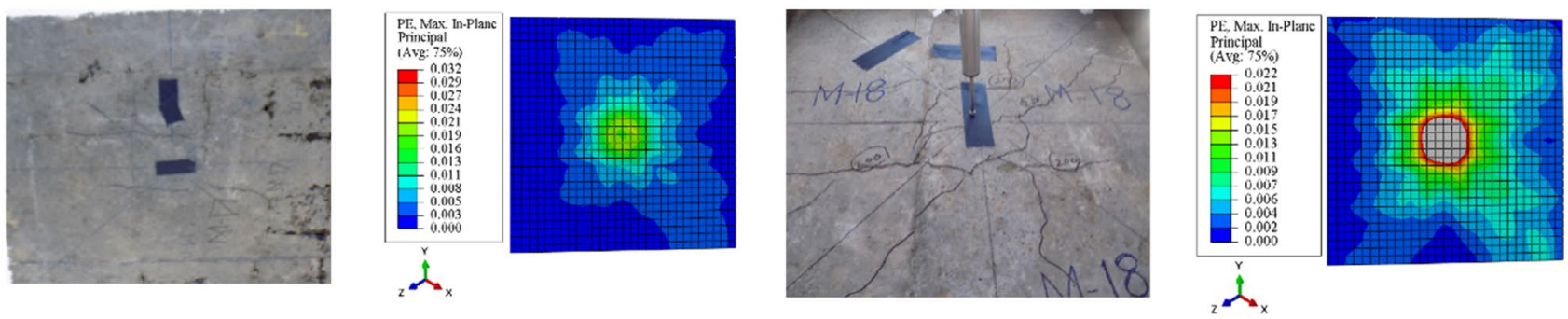

S2M-17

S2M-18

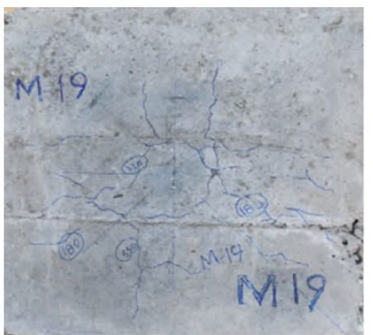

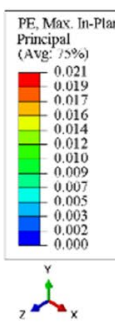

S2M-19
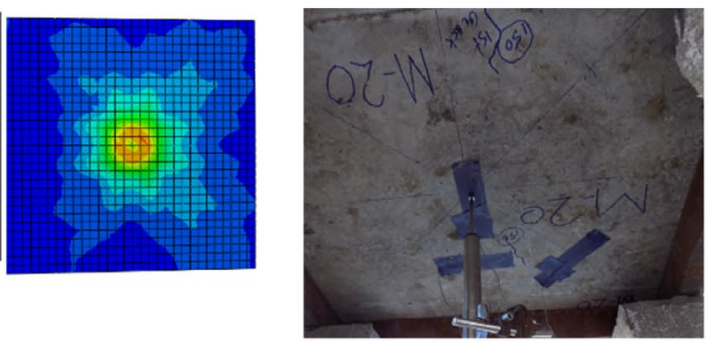

S2M-20
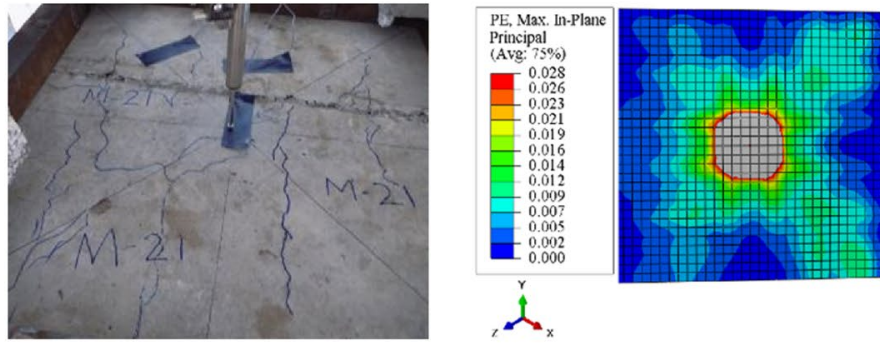

S2M-21

Fig. 22 Experimental and numerical crack patterns of two-way HFRC slabs with $1.0 \%$ steel fibers
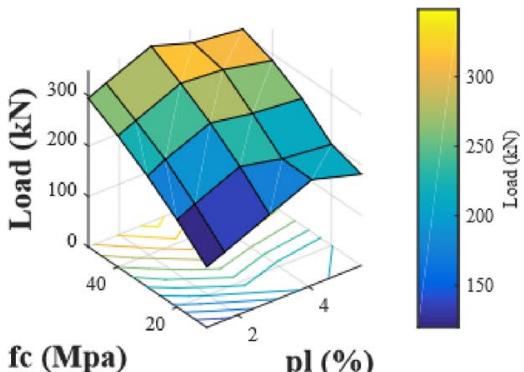

l (\%)
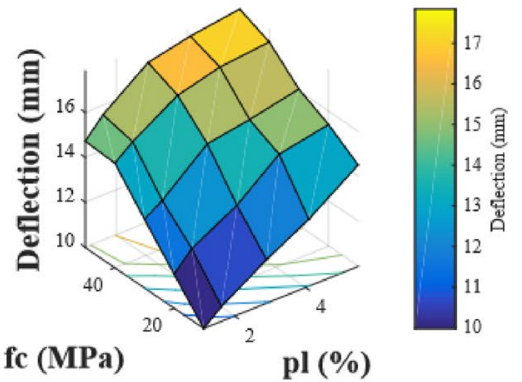

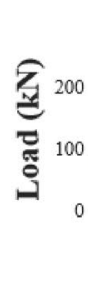

cc (mm)

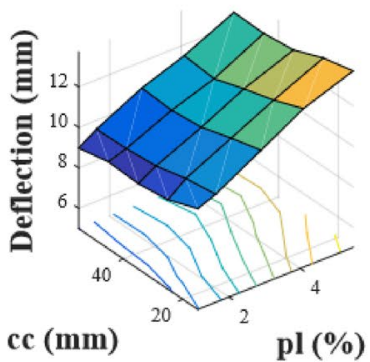

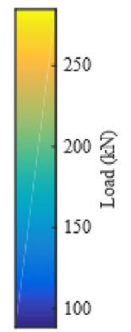

fc (Mpa)

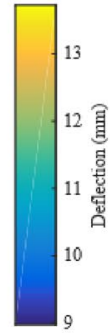

(\%)
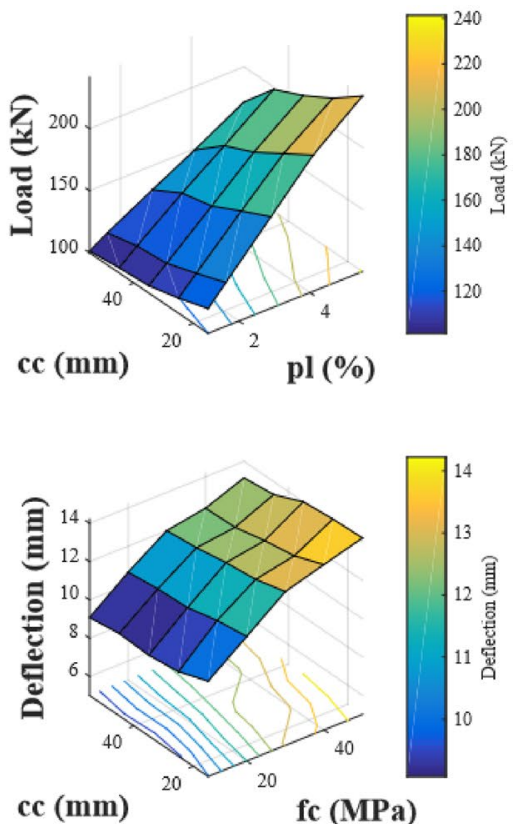

Fig. 23 Parametric study results for HFRC two-way slab specimens 
Acknowledgements The authors acknowledge the provision of Concrete Lab by the Department of Civil Engineering, UET Taxila for casting and testing of the specimens.

\section{Compliance with ethical standards}

Conflict of interest The authors whose names are listed in this paper certify that they have NO affiliations with or involvement in any organization or entity with any financial interest (such as honoraria; educational grants; participation in speakers' bureaus; membership, employment, consultancies, stock ownership, or other equity interest; and expert testimony or patent-licensing arrangements), or non-financial interest (such as personal or professional relationships, affiliations, knowledge or beliefs) in the subject matter or materials discussed in this manuscript.

Open Access This article is licensed under a Creative Commons Attribution 4.0 International License, which permits use, sharing, adaptation, distribution and reproduction in any medium or format, as long as you give appropriate credit to the original author(s) and the source, provide a link to the Creative Commons licence, and indicate if changes were made. The images or other third party material in this article are included in the article's Creative Commons licence, unless indicated otherwise in a credit line to the material. If material is not included in the article's Creative Commons licence and your intended use is not permitted by statutory regulation or exceeds the permitted use, you will need to obtain permission directly from the copyright holder. To view a copy of this licence, visit http://creativecommons .org/licenses/by/4.0/.

\section{References}

1. Gu DS, Wu YF, Wu G, Wu ZS (2012) Plastic hinge analysis of FRP confined circular concrete columns. Constr Build Mater 27(1):223-233. https://doi.org/10.1016/j.conbuildma t.2011.07.056

2. Barrera AC, Bonet JL, Romero ML, Miguel PF (2011) Experimental tests of slender reinforced concrete columns under combined axial load and lateral force. Eng Struct 33(12):3676-3689

3. Bayramov F, Taşdemir C, Taşdemir MA (2004) Optimisation of steel fibre reinforced concretes by means of statistical response surface method. Cement Concr Compos 26(6):665-675

4. Mohammadi Y, Singh SP, Kaushik SK (2008) Properties of steel fibrous concrete containing mixed fibres in fresh and hardened state. Constr Build Mater 22(5):956-965

5. Falkner H, Henke V (1998) Application of steel fiber concrete for underwater concrete slabs. Cement Concr Compos 20:377-385. https://doi.org/10.1016/s0958-9465(98)00005-5

6. Buratti N, Ferracuti B, Savoia M (2013) Concrete crack reduction in tunnel linings by steel fiber-reinforced concretes. Constr Build Mater 44:249-259. https://doi.org/10.1016/j.conbu ildmat.2013.02.063

7. Mandhkan M, Azizkhani R, Harchegani MET (2012) Effects of pozzolans together with steel and polypropylene fibers on mechanical properties of RCC pavements. Constr Build Mater 26:102-112. https://doi.org/10.1016/j.conbuildma t.2011.05.009

8. Soutsos MN, Le TT, Lampropoulos AP (2012) Flexural performance of fiber reinforced concrete made with steel and synthetic fiber. Constr Build Mater 36:704-710. https://doi. org/10.1016/j.conbuildmat.2012.06.042
9. Barluenga G, Hernandez-Olivares F (2007) Cracking control of concretes modified with short AR-glass fibers at early age. experimental results on standard concrete and SCC. Cem Concr Res 37:1624-1638. https://doi.org/10.1016/j.cemco nres.2007.08.019

10. Banthia N, Gupta R (2006) Influence of polypropylene fiber geometry on plastic shrinkage cracking in concrete. Cem Concr Res 36:1263-1267. https://doi.org/10.1016/j.cemco nres.2006.01.010

11. Chen B, Liu J (2004) Residual strength of hybrid-fiber-reinforced high-strength concrete after exposure to high temperatures. Cem Concr Res 34(6):1065-1069

12. Sun W, Chen H, Luo X, Qian H (2001) The effect of hybrid fibers and expansive agent on the shrinkage and permeability of high-performance concrete. Cem Concr Res 31(4):595-601

13. Banthia N, Sappakittipakorn M (2007) Toughness enhancement in steel fiber reinforced concrete through fiber hybridization. Cem Concr Res 37(9):1366-1372

14. Atiş CD, Karahan $O$ (2009) Properties of steel fiber reinforced fly ash concrete. Constr Build Mater 23(1):392-399

15. Ahmad A, Tahir F, Mehboob S, Raza A (2019) Proposed equation of elastic modulus of hybrid fibers reinforced concrete cylinders. Tech J UET Taxila 24(01):9-20

16. Banthia N, Gupta R (2006) Influence of polypropylene fiber geometry on plastic shrinkage cracking in concrete. Cem Conc Res 36(7):1263-1267

17. Afroughsabet V, Geng G, Lin A, Biolzi L, Ostertag CP, Monteiro PJ (2019) The influence of expansive cement on the mechanical, physical, and microstructural properties of hybrid-fiberreinforced concrete. Cem Concr Compos 96:21-32

18. Li Y, Tan KH, Yang EH (2019) Synergistic effects of hybrid polypropylene and steel fibers on explosive spalling prevention of ultra-high performance concrete at elevated temperature. Cem Concr Compos 96:174-181

19. Padanattil A, Karingamanna J, Mini K (2017) Novel hybrid composites based on glass and sisal fiber for retrofitting of reinforced concrete structures. Constr Build Mater 133:146-153

20. Labib WA (2020) Evaluation of hybrid fibre-reinforced concrete slabs in terms of punching shear. Constr Build Mater 260:119763

21. Meng Q, Wu C, Hao H, Li J, Wu P, Yang Y, Wang Z (2020) Steel fibre reinforced alkali-activated geopolymer concrete slabs subjected to natural gas explosion in buried utility tunnel. Constr Build Mater 246:118447

22. McMahon JA, Birely AC (2018) Service performance of steel fiber reinforced concrete (SFRC) slabs. Eng Struct 168:58-68

23. Sermet F, Ozdemir A (2016) Investigation of punching behaviour of steel and polypropylene fibre reinforced concrete slabs under normal load. Procedia Eng 161:458-465

24. Salehian H, Barros JA (2017) Prediction of the load carrying capacity of elevated steel fibre reinforced concrete slabs. Compos Struct 170:169-191

25. Fuzail Hashmi A, Shariq M, Baqi A (2020) Successive sustained loading effect on the long-term deflection of flat slab. SN Appl Sci 2(11):1-12

26. Shi Y, Swait T, Soutis C (2012) Modelling damage evolution in composite laminates subjected to low velocity impact. Compos Struct 94(9):2902-2913

27. Matthews FL, Davies GA, Hitchings D, Soutis C (2000) Finite element modelling of composite materials and structures. Elsevier, Amsterdam

28. Chowdhury M, Islam M, Ibna Zahid Z (2016) Finite element modeling of compressive and splitting tensile behavior of plain concrete and steel fiber reinforced concrete cylinder specimens. Adv Civil Eng 2016:1-11

29. El-Mal HA, Sherbini A, Sallam H (2015) Mode II fracture toughness of hybrid FRCs. Int J Concr Struct Mater 9(4):475-486 
30. ASTM-C150/C150M-19a (2019) Standard Specification for Portland Cement, ASTM International, West Conshohocken, PA

31. ASTM-C33/C33M-18 (2018) Standard Specification for Concrete Aggregates, ASTM International, West Conshohocken, PA

32. ASTM-A820/A820M-16 (2016) Standard Specification for Steel Fibers for Fiber-Reinforced Concrete, ASTM International, West Conshohocken, PA

33. Söylev T, Özturan T (2014) Durability, physical and mechanical properties of fiber-reinforced concretes at low-volume fraction. Constr Build Mater 73:67-75

34. ASTM-C494/C494M-17 (2017) Standard Specification for Chemical Admixtures for Concrete, ASTM International, West Conshohocken, PA.

35. Dassault Systèmes (2014) Abaqus 6.14 Documentation. Providence, RI: Dassault Systèmes

36. Kmiecik P, Kamiński M (2011) Modelling of reinforced concrete structures and composite structures with concrete strength degradation taken into consideration. Arch Civil Mech Eng 11(3):623-636

37. Piscesa B, Attard MM, Samani AK (2017) Three-dimensional finite element analysis of circular reinforced concrete column confined with FRP using plasticity model. Procedia Eng 171:847-856
38. Alfarah B, López-Almansa F, Oller S (2017) New methodology for calculating damage variables evolution in plastic damage model for RC structures. Eng Struct 132:70-86. https://doi. org/10.1016/j.engstruct.2016.11.022

39. British Standard Institution (2004) Eurocode 2: Design of concrete structures: Part 1-1: General rules and rules for buildings. British Standards Institution

40. Raza A, Khan QUZ, Ahmad A (2019) Numerical Investigation of Load-Carrying Capacity of GFRP-Reinforced Rectangular Concrete Members Using CDP Model in ABAQUS. Adv Civil Eng 2019:1-21

41. ASTM-C143/C143M-15a, (2015) Standard Test Method for Slump of Hydraulic-Cement Concrete, ASTM International, West Conshohocken, PA

42. ACl Committee. (1982) State of the Art Report in Fiber Reinforced Concrete. $\mathrm{ACl}$ (American Concrete Institute): Farmington Hills, MI, USA

Publisher's Note Springer Nature remains neutral with regard to jurisdictional claims in published maps and institutional affiliations. 